\title{
Water: Turkish Prospective Biology Teachers' Conceptual Structures and Semantic Attitudes towards Water
}

\author{
Hakan Kurt ${ }^{1}$ \\ ${ }^{1}$ Ahmet Kelesoglu Education Faculty, Necmettin Erbakan University, Konya, Turkey \\ Correspondence: Hakan Kurt, Ahmet Kelesoglu Education Faculty, Necmettin Erbakan University, Konya, 42090, \\ Turkey. Tel: 90-506-854-2647. E-mail: kurthakan1 @ gmail.com
}

Received: September 5, 2018

Accepted: September 21, 2018 Online Published: October 9, 2018

doi:10.5539/hes.v8n4p77

URL: https://doi.org/10.5539/hes.v8n4p77

\begin{abstract}
This study was prepared to investigate prospective biology teachers' cognitive structures related to "water". As the research design of the study, the case study was applied. The data were collected from 44 prospective biology teachers. The free word-association test, the drawing-writing technique and the semantic differential attitude scale were used as data collection instruments. The data were subject to content analysis and divided into categories through coding. In the analysis, the categories were formed and determined through the results of word-association test and drawing-writing test which were completed by the prospective biology teachers. With the help of these categories, the cognitive structures of prospective biology teachers were explained. These categories were determined as "the place and importance of water in life, the definition and chemical properties of water and water and metabolism". It was determined that prospective biology teachers' semantic attitudes towards water were at a positive level in terms of mean scores of all adjectives considered; However based on each and every adjective, they mostly perceive water as compulsory, valuable and necessary. Moreover, the data collected through three data collection instruments indicated that prospective biology teachers had misconceptions about water considering the categories determined.
\end{abstract}

Keywords: water, free word association test, drawing and writing technique, semantic differential attitudes scale, cognitive structure, misconception

\section{Introduction}

When the sea level rises, fish endeavor ants; when the water recedes, ants endeavor fish. In other words, superiority shifts from fish to ants, and vice versa.

The superiority brought about by being an ant or fish does not mean anything but fooling oneself, because the subject and object depend on the movement of water.

Water is an extremely mysterious natural resource which exists all the time, either in a visible or non-visible way depending on its location. In this respect, it is one of the most significant substances that have always had an influence on human life. The reason for this is that water is a fundamental building block that can be found in large amounts in all creatures. As stated by Akin and Akin (2011), water has always been necessary for human beings to perform such vital activities as nutrition, circulation, respiration, excretion and reproduction. In addition to being a fundamental factor in the formulation of a quality living environment, water is also a living environment on its own. Because it is a sine qua non for life, it is essential that high-quality water should be existent in the living environment. Water is one of the fundamental elements of life. As well as being a basic food, it plays an incredibly active role in a number of biochemical reactions happening in our body thanks to the minerals and compounds it contains. It performs a wide range of tasks from maintaining $\mathrm{pH}$ balance to providing a dispersion medium for molecules and organelles in cells, and to transferring waste to relevant locations.

A life without water cannot be imagined, for water is everything to living beings and liveliness. As well as being a prerequisite for liveliness, water is also a living environment for living beings (Akin, Gulec, Sagir, Gultekin, \& Bektas, 2005). In this respect, the consumption of water, which is such an invaluable substance for creatures, presents itself as a highly important subject. Occupying a prominent place in the life of all living beings, water is a significant concept not only for daily life but also academic life. That is because water is included among the fundamental concepts to be learned within the scope of many courses such as physics, chemistry, biology, 
geography, history, hygiene etc. Since this concept concerns many disciplines, it causes students to have difficulty in forming conceptual structures related to the concept of water. The causes why students are successful or unsuccessful in learning concepts are important leading issue in educational research for an effective learning. In this sense concepts need to be structured appropriately in students' minds (Tatar \& Koray, 2005). In the current study, prospective biology teachers' conceptual structures related to water, were investigated through versatile perspectives using the free word-association test, the drawing-writing technique in addition to the semantic differential attitude scale.

\subsection{The Studies Conducted on Conceptual Structures of Water Concept}

There are many studies conducted to investigate students' conceptual structures about the concept of water. Each stage of the educational life places emphasis on such issues as the structure of water, water cycle, characteristics of water, water pollution and pollutants, the effect of water on human beings and transportation of water. Even so, it has been found that both students and prospective teachers/teachers have misconceptions about these issues (Stavridou \& Marinopoulos, 2001).

A review of literature suggests that studies are commonly focused on the opinions of participants about water, their conceptual structures, its meanings and alternative concepts. There are studies on revealing the conceptual structures of children about the states of water (Osborne \& Cosgrove, 1983), evaporation and phase transition (Bar \& Galili, 1994; Bar \& Travis, 1991), of students aged between 10 and 18 years old about condensation, boiling, evaporation and states of water (Hatzinikita \& Koulaidis, 1997), of secondary school students about atmospheric water vapor and evaporation at room temperature (Johnson, 1998), of children aged between 1 and 6 years old about condensation and evaporation in a comparative manner (Tytler, 2000), of primary schools about air and water pollution (Stavridou \& Marinopoulos, 2001), of high school and first grade university students about water literacy levels (Ewing \& Mills, 2004), of primary schools students about the states of water (Boo, 2006), of students of various age groups about water (Thompson and Logue, 2006), of high school students about solubility (Koray, Akyaz, \& Koksal, 2007), of first grade university students about boiling (Costu, Ayas, Niaz, Unal, \& Calik, 2007), and of primary school students about water (Gooding \& Metz, 2011). However, the number of studies on university students seems to be limited.

On the other hand, a great majority of the studies conducted on water discussed only misconceptions. One of the fundamental reasons for this is that misconceptions contribute to students' academic failure. Misconceptions are not based on scientific facts and lead to difficulties in acquiring scientific knowledge. As a result, misconceptions make it more difficult to learn the concept of water concerning a variety of disciplines. Determining students' misinformation and lack of learning in their previous knowledge plays a crucial role in preventing future misconceptions (Seloni, 2005), and stressing the points that need special care while acquiring new knowledge.

Several studies have also revealed that participants have certain misconceptions. For instance, students reported that clouds contain water and come down to the ground in the form of rainfall (Thompson and Logue, 2006), in addition, student teachers and students have misconceptions about the solubility of a chemical in water (Haidar \& Abraham, 1991; Martin, 2001), and student chemistry teachers have misconceptions about evaporation and dewing (Haland, 2010). Studies have identified that students have difficulty in understanding the water cycle (Ben-Zvi Assaraf \& Orion, 2010a) that their misconceptions resist change even after formal learning, and that learning often fails to overcome such misconceptions (Ben-Zvi Assaraf \& Orion, 2005a). It has been discovered that most students limit watershed hydrology to condensation, evaporation and precipitation (Shepardson, Wee, Priddy, Schellenberger, \& Harbor, 2007), whereas high school students have difficulty in understanding the processes of evaporation under normal circumstances (Bar \& Galili, 1994).

Students have been found to hold misconceptions about pollution, too. In one study, they reported that such situations as water pollution and consumption that have an effect on the water cycle and distribution of water resources have nothing to do with human-based activities (Agelidou, Balafoutas, \& Gialamas, 2001). In another study, primary school students had misconceptions about water pollution (Stavridou \& Marinopoulos, 2001). It was revealed that only $7 \%$ of the drawings made by students regarding the concepts of watershed hydrology could express the interrelated concepts between watershed hydrology and water cycle (Dove, Everett, \& Preece, 1999). Furthermore, students prove to be weak at understanding the link between plants and underground water (Ben-Zvi Assaraf, Eshach, Orion, \& Alamour, 2012) and believe that plants can be grown in water without necessarily having soil (Barman, Stein, McNair, \& Barman, 2006). They frequently fail to comprehend the geosphere (Ben-Zvi Assaraf et al., 2012). Most students regard underground waters as an independent system (inactive, lake, etc.) not linked with surrounding rocks (Ben-Zvi Assaraf \& Orion, 2005a,b). In her study, 
Ben-Zvi Assaraf et al. (2012) reported that students have insufficient "perceptions of the source of rain", "explanations for water flow in the geosphere", "explanations for water intake in plants" and "perceptions of human beings within the scope of water systems". Similarly, Taiwo, Ray, Motswiti and Masene (1999) discovered that students have conflicting perceptions of the formation of clouds, precipitation and rainbow".

A number of studies have identified that high school and university students of biology have misconceptions about osmosis and diffusion. For instance, high school students were found to have misconceptions about "concentration and flexibility, the effect of osmosis and diffusion on life force, the kinetic energy of matter, membranes, the characteristics and casualness of the matter, processes of diffusion and processes of osmosis" (Fisher, Williams, \& Lineback, 2011; Odom \& Barrow, 2007; Zuckerman, 1998). In addition, students of biology have wrongly think that photosynthesis occurs without water (Hill, 1997) and students have reported that soil provides plants with food and water, and that plants feed on water (Anderson, Sheldon, \& DuBay, 1990; Kose, 2008; Songer \& Mintzes, 1994; Tekkaya \& Balci, 2003).

When it comes to water, such issues as water, lack of water, water pollution, water consumption and careful use of water present themselves as significant problems afflicting societies (Mohapatra \& Bhadauria, 2009). In recent years, environmental issues, especially pollution problems, have been widely discussed all around the globe. Students often regard pollution as something that has a negative influence on living beings. However, students report that the negative effect of air pollution on plants does not pose an ecological problem (Brody, 1994), which suggests a clear misconception on the part of students. In general, students note that not everything in nature is polluted and that not everything existent in nature or occurring in the world gives rise to pollution. Even so, they believe that all that is produced for human race is harmful and brings about pollution (Ali, 1991; Brody, 1991, 1994; Boys \& Stanisstreet, 1994; Boyes, Stanisstreet, \& Spiliotopoulou-Papantoniou, 1999).

As indicated in the related literature, almost all of the studies conducted on this issue included the participants of educational institutions excluding universities. In this vein, to the best knowledge of the author, there is not any study conducted to determine prospective teachers' and teachers' conceptual structures about water. The results of the current study are important, considering that the participants included particularly prospective biology teachers. In the following section, the tests of free word association, and the drawing-writing technique, and the scale of semantic differential attitudes were discussed, providing examples from the related literature, and later other examples were provided of the studies conducted particularly on water through using these techniques.

Free Word-Association Test; Free word-association test is one of the most general and the oldest techniques that investigate students' cognitive structure. Free word-association test is a data collection technique used to determine individual's conceptual structures related to a concept. Concerning the literature review conducted, there is not any study conducted to investigate the participants' conceptual structures about the concept of water using the free- word association test. Therefore, it is believed that the results of the current study will fill this gap in the related literature.

Drawing-Writing Technique; Drawing-writing technique is an efficient technique used to reveal students' learning thoroughly. A review of literature reveals that it is drawing technique that is most commonly used for identifying conceptual structures of individuals regarding water. Concerning the studies conducted in this context, in one of such studies by Cin (2004), the figures in the drawings of primary school students about sea included blue, fish living in the sea, people swimming in the sea, something large, wavy, long and salty. In addition, Dove et al. (1999) attempted to identify the hydrologic concepts of primary school students aged between 9 and 11 years old on the basis of their drawings. Most of the students drew rivers flowing down from the right or left side of the page. Their drawings of rivers were grouped under three categories and words distributed across these categories, namely river characteristics, riverside characteristics and landscape characteristics. In an attempt to explain the difference between belief and understanding, Reis et al. (2002) presented sample drawings of water by students and scientists. The author compared the students' drawings of water (symbolic drawings) with those of scientists and revealed that the former were not scientific; therefore, the students could not have understood water and remained at the level of belief. Furthermore, in a study by Nyachwayaa et al. (2011), students formulated water using hydrogen $(\mathrm{H})$ and oxygen $(\mathrm{O})$. They expressed chemical molecules using models or drawings as well as employing such terms as components of atoms, molecules and ions. However, it was observed that the students did not use ions in their drawings. Reinfried, Tempelmann and Aeschbacher (2012), identified secondary school students' misconceptions about water springs in accordance with their drawings. In another study, Dickerson and Dawkins (2004) reported that secondary school students had alternative concepts to underground waters. The students mostly used such terms as "underground streams" and "underground pools". Ben-Zvi Assaraf (2012) analyzed the drawings of fourth grade primary school students with different cultural backgrounds regarding the water cycle and could form the following categories: the atmosphere, the hydrosphere, 
the biosphere and the geosphere. As regards these categories, there was a significant difference between rural students and semi-urban students, the difference being in favor of those living in rural areas.

In another study, Shepardson, Wee, Priddy, Schellenberger, \& Harbor (2009) revealed disconnected concepts of students aged 4 to 12 years old concerning the hydrologic cycle. Their drawings yielded four categories. The first category included water storage, transformation and transportation in different ways. The students thought of a hydrologic cycle involving water transportation, water storage and water transformation. Similarly, Celikler and Topal (2011) assessed prospective science teachers' knowledge about the water cycle and carbon dioxide through drawings. They found that they had taken into account neither the effects of living beings on the water cycle nor photosynthesis in the carbon dioxide cycle, which suggested that they had some imperfect knowledge.

There are also many studies conducted using drawing-writing technique. In this regard, Rundgren, Rundgren, \& Schönborn, (2010) conducted a study on those students enrolling in chemistry-biology and those students not enrolling in science courses and collected data on water transportation from the cell membrane. Among the most significant misconceptions were their unawareness of the specialized water channels in water transportation and their faulty thinking that most water molecules would cross the hydrophobic membrane diagonally through direct diffusion. In another studies, were conducted on issues such as primary school teachers' levels of understanding the biological concepts of gas exchange in photosynthesis and respiration processes (Lenton \& McNeil, 1993), water cycle and environment for primary school students (Dove et al., 1999) and water systems (Ben-Zvi Assaraf \& Orion, 2010b).

Attitudes towards the Concept of Water; In literature, attitude is defined as "the core of human individuality", "the permanent organization of an individual's motivational, emotional, perceptional and mental processes towards an event or a psychological object", "positive or negative sensual intensity", and "learned tendency" (Bohner \& Wanke, 2002; Fishbein \& Ajzen, 1975; Muller, 1986). Attitudes, through cognitive, emotional and behavioral dimensions, play an important role in individuals' learning (Anderson, 1988; Bagozzi \& Burnkrant, 1985; Bloom, 1979). In this process, In this process, it is important that they adopt the facts when adopting attitudes (Verplanken and Hofstee, 1998). It is a long and important process for individuals to adopt and change attitudes.

Since it is widely known that there is a positive relationship between cognitive success and emotional success, it is important for the teaching method to be followed when the individual adopts behavioral goals (Bloom, 1979). Attitudes can be measured by direct or indirect measurement techniques (Kagitcibasi, 2010).

In the current study, prospective biology teachers' attitudes towards water were investigated through applying semantic differential attitude scale for the concept of water. However, when the related literature is concerned, to the best knowledge of the author, there is not any study that carries out such an evaluation. It is determined that the studies conducted on the attitudes towards water generally focus on certain issues. There are also other studies on attitudes towards the protection of underground waters (Lord \& Bummer, 1992; Thayer, 1982), attitudes of people from different countries towards water (Lee, 2009), attitudes towards the use / thrifty use of water (Aitken, McMahon, Wearing, \& Finlayson, 1993; Cheam, 2012; Gilbertson, Hurlimann, \& Dolnicar, 2010; Gilg \& Barr, 2006; Hurliman \& Dolnicar, 2010; McPeak, 2009), attitudes toward water subjects (Ballweg, 1972; Duda, 2005; Praneetham \& Thathong, 2012; Sari, Kärkkäinen, \& Keinonen, 2011), responsibilities of people for the use of water (Thayer, 1982) and awareness of water (Anderson, 2010; Damanhouri, Al-Saleem, \& AL-Ali, 2012).

\subsection{Significance of the Research}

As can be seen in the studies, at each and every level of education, students and teachers had many alternative concepts. At this point, through applying triangulation and using free word-association test and drawing-writing technique, prospective biology teachers' conceptual structures can be determined, and their alternative concepts can be revealed. However, in the literature review on this issue, it is found out that there are a few studies using both free word-association test and drawing-writing technique to reveal prospective biology teachers' conceptual structures related to "water". Therefore, it is believed that the results of the current study conducted through using free-word association test and drawing-writing technique will fill this gap in the literature providing data of quality. Moreover, there is not any study that investigates prospective biology teachers' semantic differences towards the concept of water, and thus, it is believed that the data collected in the current study will contribute to the literature. Water is one of the important concepts that individuals face at any time in their lives, and whose effects either positive or negative can be felt. Considering the issue from prospective biology teachers' perspective, it is important for them to be competent in this subject as it will be their duty to teach the concept of water and related information to students effectively and correctly during their professional life. The aim of the 
current study is to investigate prospective biology teachers' cognitive structures related to "water". In this vein, the following research questions were investigated:

1. What is the prospective biology teachers' cognitive structures related to "water" using the free word-association test and the drawing-writing technique?

2. How are the prospective biology teachers' attitudes towards the concept of water?

3. What are the prospective biology teachers' misconceptions about the concept of water?

\section{Method}

The study was conducted through case study design which was found among qualitative research approach. Case study is a research design that is in the foreground to reveal how a group sharing similar characteristics reacts to a certain situation. According to Yildirim and Simsek (2006), case study is a research method which aims to provide an opportunity to reveal a fact with the perspective of related individuals. In this research design, through three types of data collection instruments, it is investigated how prospective biology teachers perceive the concept of water and how their cognitive structures evolve.

\subsection{Sample}

The study was comprised of 44 prospective biology teachers studying at the $4^{\text {th }}$ and $5^{\text {th }}$ grades of Ahmet Kelesoglu Faculty of Education in Necmettin Erbakan University. This study benefited from purposive sampling. Some criteria were taken into consideration in order to minimize the problems in purposive sampling (Knight et al., 2013). In this vein, several criteria were taken into consideration while selecting the participants such as having completed the field courses in Biology, willingness to participate in the study, being seniors in the department of Biology teaching and having completed the courses, and being available to the researcher. Moreover, the prospective biology teachers were informed by the researcher of the aim of the study and how to complete the measurement tool.

\subsection{Data Collection}

These types of measurement tools were used as the data collection instrument in the current study. These are: the free word-association test, the drawing-writing technique and the semantic differential attitude scale of the concept of water. The main purpose of using different data collection tools is to increase consistency, intelligibility and actuality (Glesne \& Peshkin, 1992; Patton, 2002; Poggenpoel \& Myburgh, 2003; Roberts Priest, \& Traynor, 2006; Shenton, 2004).

A Free Word Association Test: A free word association test is a technique which aims to determine a student's or a group's conceptual framework. This technique is quite efficient in revealing individuals' cognitive structures and conceptual changes (Hovardas \& Korfiatis, 2006). Free word association tests are used in many studies (Ad \& Demirci, 2012; Bahar, Johnstone \& Sutcliffe, 1999; Koseoglu and Bayir, 2011; Ozatli and Bahar, 2010; Kurt, 2013a, b) aims to determine the relationship between the cognitive structure of the student and the concepts in this structure (long term memory). This technique is based on the process in which an answer is suggested to a word that is used as an independent stimulus without limiting the mind to any specific response (Bahar et al., 1999; Sato \& James, 1999). The participants are required to provide the concepts that come to mind at a given time (40 seconds) (Gussarsky \& Gorodetsky, 1990), the words that are provided as answers are subject to frequency distribution that is followed by an in-depth analysis. In this way, it is possible to determine the participants' descriptions and gather findings on the related meanings of the word used as a stimulus. These practices of using free word association tests help reveal the meanings related to various concepts used in studies (Daskolia, Flogaitis, \& Papageorgiou, 2006). The word association test consists of two sections (Figure 1);

In The First Section: The biology prospective teachers were asked to provide the very first 10 words that come to their minds in 40 seconds when they read or hear the concept "Water". The key concept is provided one under the other in order to prevent sequential answering as they would just consider their answer and provide the words regarding that word rather than focusing on the key concept, which would threaten the validity and the reliability of the study. In this study, the concept of "Water" has been provided for the biology prospective teachers to complete the free word association test. In this test, the concept of water has been provided in the following format as the stimulus word;

Water-1 :

Water-2 :

Water-10 : 


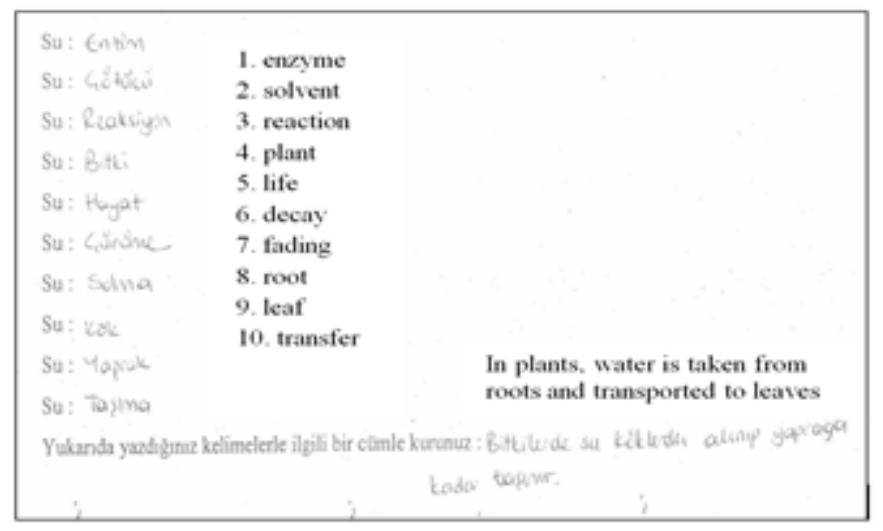

Figure 1. The Examples of Free Word-Association Test (P30)

In The Second Section: Participants were asked to write a sentence about the key concept in a given 20 seconds. The answer associated with the key concept may also be a connotation product that does not have a meaningful relationship to the key concept at the level of recall. Also relevant sentence more complex than a single word answers and the lack of top-level structure of the sentence is to be scientific, whether it includes different misconceptions considering the possibility that the sentence provided can be more complex and of high structure. At this stage, the participants were asked questions such as "Please write a sentence on the concept of water".

Drawing-Writing Technique: This technique is very crucial in that it helps collect natural and high quality data on students' hidden thoughts, understanding, points of view, attitudes, etc. (Garland, 2005; Levin \& Bus, 2003; Pridmore \& Bendelow, 1995). In addition, the drawing technique is very effective in terms of time management, since it is more convenient than other methods such as writing and behavior scales used to reveal changes of opinion, understanding and attitude, and allows the collection of data from various perspectives. It is also effective because it can be easily internalized (Atasoy, Kadayifci, \& Akkus, 2007).

On the other hand, it is aimed to investigate the views of prospective biology teachers about water concept by using drawing-writing technique (Rennie \& Jarvis, 1995). This technique is very useful because it helps to collect natural and quality data about latency thoughts, understanding and attitudes during the study (Backett-Milburn \& Mckie, 1999; Hayes, Symington and Martin, 1994; Pridmore \& Bendelow, 1995; Reiss, et al., 2002; White \& Gunstone, 1998). In this context, participants were asked to present their views freely within 5 minutes without any limitation to the question "What is water? What do you think about water? Please describe it by drawing "(Williams, Wetton, \& Moon, 1989). Below are some examples of the drawing-writing technique (Figure 2 and Figure 3).

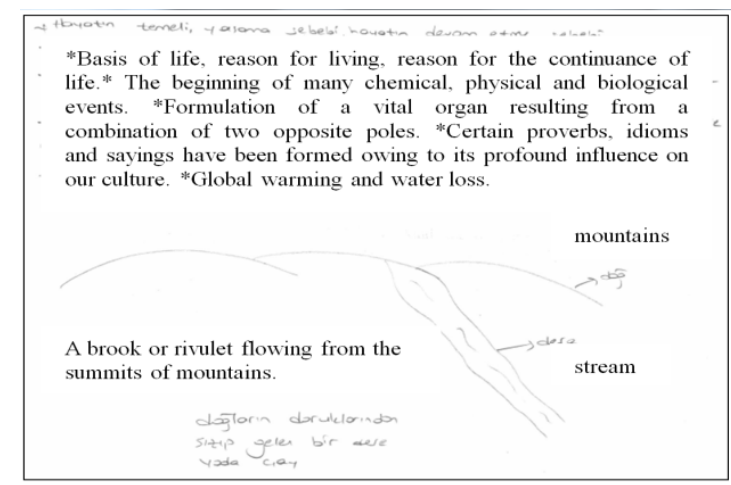

Figure 2. The Examples of Drawing-Writing

Technique. The Answer Sheet for (P15) 


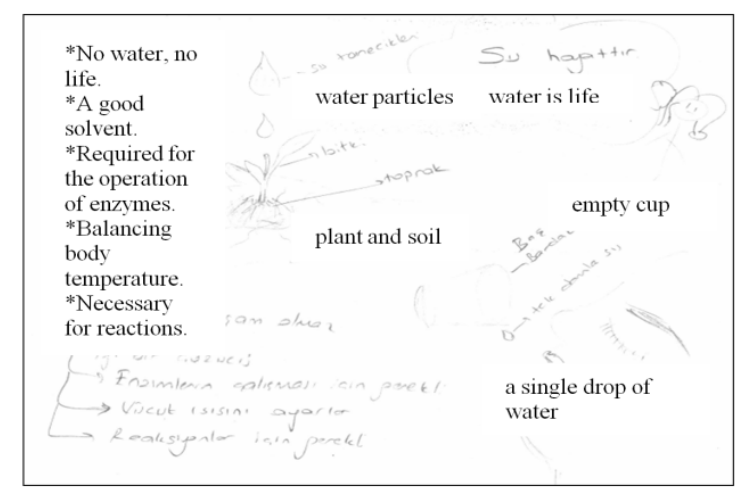

Figure 3. The Examples of Drawing-WritingTechnique.

The Answer Sheet for (P38)

Semantic Differential Attitudes Scale of the Concept of Water: The scale wants participants to rate the concept of water according to their semantic differences and aims to reveal the participants' attitudes towards water. On this scale, the participants choose one of the adjectives in the opposite poles by considering their suitability to the water concept. This scale was measured by Osgood et al. (Russell and Hollander, 1975), proves to be effective in determining emotional features (Anderson, 1987).

A scale of 5 or 7 points was used in this scale. A unipolar scale. It is a single pole rating scale defined by two opposite characteristics at opposite poles. In this study, the scale was designed and applied to the participants as a 5-Likert scale with appropriate attributes appropriate for the water concept. Studies investigating the relevant attitudes in determining the adjectives were taken into consideration (Ballweg, 1972; Cheam, 2012; Dickerson, Callahan, Sickle and Hay, 2005; Duda, 2005; Hurliman \& Dolnicar, 2010; McDaniels, Axelrod, \& Cavanagh, 1998; Praneetham \& Thathong, 2012; Sari et al., 2011; Thayer, 1982) and general adjectives are selected so that they are not associated with the specific dimensions of the subject. In biology education, two experts and measurement and evaluation were asked to seek advice during the development of the scale. Adjectives were evaluated as positive, negative, always ( 5 points), usually (4 points), sometimes ( 3 points), generally ( 2 points) and always (1 point). Following the calculation of each frequency, percentage and arithmetic values of each bipolar adjective, total attitude scores were calculated by taking the average of the responses of each 10 pairs. If participants' scores fell to 5 and 4 options, they were expected to adopt positive attitudes; If they fell to 3 , they were supposed to adopt neutral attitudes, and if 2 and 1 were thinking of adopting negative attitudes. In this vein, the average positive attitudes of 3.5 and above; While 2.5 and 2.5 were average neutral attitudes, 2.5 and lower mean negative attitudes (Lohr and Bummer, 1992). Cronbach's alpha reliability coefficients were found to be 0.90 according to semantic differential attitude scale. In this context, the participants were given a semantic different attitude scale related to the question "which features do you find related to the water concept? The following are examples of the semantic differential attitude scale of the water concept.

$$
\begin{gathered}
\text { Required...... } \square \ldots \ldots \square \ldots \ldots \square \ldots \ldots \square \ldots \ldots . \ldots \ldots . . \text { Not required } \\
\text { Sustainable............................ }
\end{gathered}
$$

\subsection{Reliability and Validity of the Data Collection Instruments}

In qualitative studies, validity means that a researcher observes the situation as objectively as possible and observes as much as possible (Yıldırım and Şimşek, 2006). It is also the approach that we believe in and plan to measure (Marvasti, 2004; Roberts et al., 2006). However, the most important problem in the validation of qualitative studies is how they can prove the objectivity of the researchers. Subjectivity may arise when researchers collect, record, or interpret data. If this quality is minimized, a qualified qualitative study will be possible (Yıldırım \& Şimşek, 2006). In this study, the internal validity of categories and subcategories is provided by two experts in biology and biology education. In addition, in this study, two important processes were carried out in order to validate the results of the study. (a) Data coding and analysis (How conceptual categories were obtained) were discussed in detail (Hruschka, et al., 2004) (b) examples of opinions believed to represent the best of each category of prospective teachers during the study are presented in the findings section (Yıldırım \& Şimşek, 2006).

Morever, to ensure the reliability of the study, the codes and categories given by the two researchers were compared to verify whether the codes presented in each conceptual category represent the above-mentioned 
conceptual categories. Two experts in the field of biology and biology education completed the list of codes and categories after the individual data was encoded. The consistency of the coding performed independently by the participants was determined by signs such as "Agreement" or "Disagreement". When the researchers used the same codes for prospective biology teachers' statements, these codes were accepted as agreement. However, when they used different codes, these codes were disagrement. When one of the researchers was unsure about coding, he asked the other's opinion and then coded the data. The reliability of the data analysis was calculated using the formula [Agreement / (Agreement + Dispute) x 100] (Miles and Huberman, 1994). The avarage reliability between the encoders was calculated as $96 \%$ for the free word-association test and $97 \%$ for the drawing-writing technique. Cronbach's alpha reliability coefficients were found to be 0.95 according to semantic differential attitude scale.

\subsection{Data Analysis}

The participants' answer sheets were numbered from 1 to 44 for data analysis. The data collected by free word association test and drawing-writing technique were analyzed according to content analysis (Finson, Beaver \& Cramond, 1995). The main purpose of content analysis is to reach the concepts and relations that can explain the data. To achieve this goal, similar data are collected and organized within specific concepts, analyzed and readily understood by the reader. (Ylldirim and Simsek, 2006).

Data collected by free word association test were analyzed by using word count, number of answers and semantic relationship techniques (Atasoy, 2004). Words with the same meanings are classified in the category of frequently mentioned words. Words that are not considered relevant, not related to other words, and 1 or fewer repeated words are not taken into account during data analysis. Words were categorized using the semantic relation criterion and frequency calculations of these words were made under each category. In many studies it has been reported that the use of such data analysis provides reliable results (Daskolia et al., 2006; Kostova and Radoynovska, 2008; Kostova and Radoynovska, 2010).

Drawing writing technique; The drawings and explanations about the concept of water have been examined in two different sections. The collected data were analyzed according to content analysis. To achieve this, the statements provided by each participant in the concept of water are organized under certain categories and subcategories. The participants' drawings about the water concept were analyzed in the same way. Many drawings that are not relevant to the subject, drawings not related to other drawings, and drawings that are repeated only once are not taken into account. Furthermore, in both the free word association test and the drawing-writing technique, the interesting expressions in the texts provided by the participants are numbered (P21). In the drawing-writing technique, samples of the drawings provided by the participants were numbered and shown in a text such as P42.

When the opinions of the participants about the semantic differential attitude scale of the water concept were evaluated, scoring from 1 to 5 was made. On the bipolar scale, positive adjectives were evaluated as 5 points and negative adjectives were evaluated as 1 point. According to this rating, there were differences between participants' positive and negative attitudes towards water. The internal validity of the categories and subcategories that emerged throughout the study was provided by two experts in biology and biology education, including the author. In addition, SPSS-20 was used to evaluate the semantic emotional difference attitude scale for water concept and Nvivo9.3 was used to construct Model 1.

\section{Results}

In this section were analyzed according to the order in which the data collection instruments were used. Therefore, firstly the data collected through the free-word association test were presented, then the data collected through the drawing-writing technique, and finally the data collected through the semantic differential attitude scale of the concept of water.

\subsection{The Results Determined Through Free Word-Association Test}

As a result of the analysis of the data collected through the free word-association test, 8 (eight) categories were specified through the words provided by the prospective biology teachers'. In this regard, the categories and the words in each category were listed. When these words were meaningless and repeated only one, they were not joined with the other words. Therefore, $17.35 \%$ (63 words) of these mentioned words were not included in the categories. As a result, these words not listed in the subcategories were not provided in Table 1. Related to the word, water, 68 words left were distributed among 8 (eight) categories. The words specified in each category and the categories were provided in Table 1.305 words were specified in total. 
Table 1. Associations with the Concept "Water" (Categories and Answers Included In Each Category and Cumulative Frequency of Response Words)

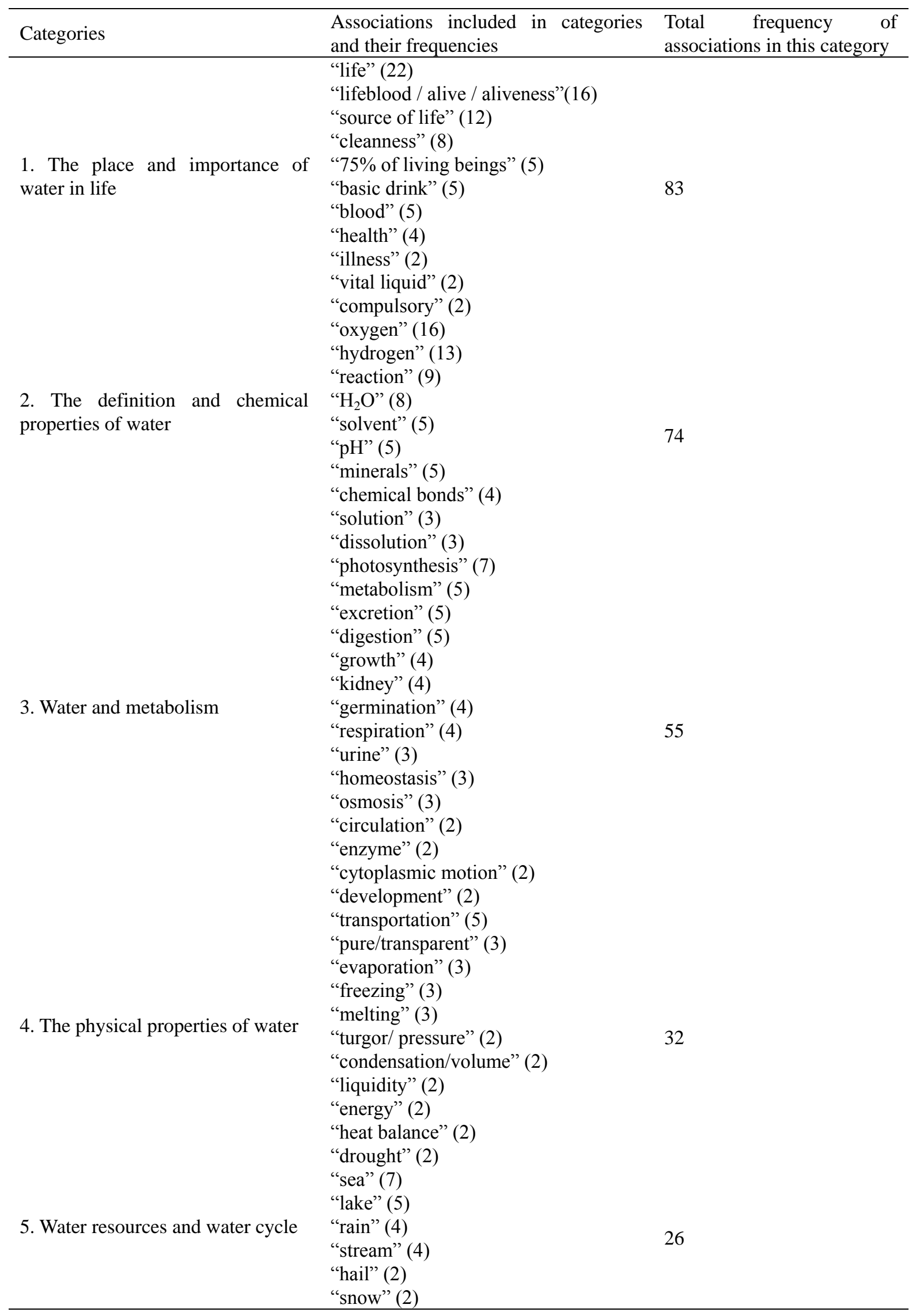




\begin{tabular}{|c|c|c|}
\hline \multirow{9}{*}{ 6. Water and species-kinds } & "ocean" (2) & \multirow{8}{*}{24} \\
\hline & “cell” (6) & \\
\hline & "plant" (6) & \\
\hline & "human" (2) & \\
\hline & “animal" (2) & \\
\hline & "root" (2) & \\
\hline & “seed (2) & \\
\hline & "fruit" (2) & \\
\hline & "leaf" (2) & \\
\hline \multirow{3}{*}{ 7. Water and environment } & “soil" (3) & \multirow{4}{*}{9} \\
\hline & " $75 \%$ of the planet being water" (2) & \\
\hline & “ecosystem”(2) & \\
\hline \multirow{3}{*}{ 8. Water pollution } & "nature/environment" (2) & \\
\hline & "water pollution" (3) & \multirow{2}{*}{5} \\
\hline & “decomposition" (2) & \\
\hline General Total & & 305 \\
\hline
\end{tabular}

As a result of the analysis of the data collected through the free word-association test and the words provided by prospective biology teachers, 8 categories were determined, namely, "The place and importance of water in life" (83), "The definition and chemical properties of water" (74), "Water and metabolism" (55), "The physical properties of water " (32), "Water resources and water cycle" (26), "Water and species-kinds" (24), "Water and environment" (9) and "Water pollution" (5).

As can be concluded from Table 1, the answers provided by the participants concerning water mainly fell into the category "the place and importance of water in life", which made it the dominant category. The answer words in this category mostly included "life", "lifeblood/alive/aliveness", "source of life", "cleanness", "75\% of living beings", "basic drink", "blood" and "health", whereas a smaller number of participants used terms like "vital liquid" and "compulsory". Moreover, the words those were provided in this category by the prospective teachers but not included in this category as they were stated only once are as follows: beauty, fade, hibernation and gill.

In accordance with the answers provided by the participants, the second category was called "the definition and chemical properties of water". The answers in this category mainly focused on such concepts as "oxygen", "hydrogen", "reaction", " $\mathrm{H}_{2} \mathrm{O}$ ”, "solvent”, " $\mathrm{pH}$ ” and "minerals” while a small number of prospective biology teachers used concepts like "chemical bonds", "solution" and "dissolution". The finding suggests that the prospective biology teachers mostly associated water with the definition and chemical properties of water. Tthe words that were provided in this category by the prospective biology teachers but not included in this category as they were stated only once are as follows: non-polar, hydrophilic, elements, CO2, polarization and fleece.

In accordance with the answers provided by the participants, the third category was named "water and metabolism". In the category, prospective biology teachers more often used such words as "photosynthesis", "metabolism”, “excretion”, “digestion”, "growth”, “kidney”, "germination” and "respiration”, whereas they less often referred to concepts like "urine”, "homeostasis”, "osmosis”, “circulation”, "enzyme”, "cytoplasmic motion" and "development". Furthermore, the words that were provided in this category by the prospective biology teachers but not included in this category as they were stated only once are as follows: the cytoplasm and oil degradation.

The fourth category was called "the physical properties of water". The associations of the prospective biology teachers were mostly based on "transportation", "pure/transparent", "evaporation", "freezing" and "melting”, while the words that were less frequently expressed included "turgor pressure", "condensation/volume", "liquidity", "energy", "heat balance" and "drought”. The participants were found to have insufficient cognitive structures considering the physical properties of water. Moreover, the words those were provided in this category by the prospective biology teachers but not included in this category as they were stated only once are as follows: clear, electrolyte and stress.

In accordance with the answers provided by the prospective biology teachers, the fifth category was called "water resources and water cycle". The participants mostly used such concepts as "sea", "lake", "rain" and "stream". The ones that were less commonly used were "hail", "snow" and "ocean". Moreover, the words that were provided in this category by the student biology teachers but not included in this category as they were stated only once are as follows: drinking water and salty waters. 
In accordance with the answers provided by the prospective biology teachers, the sixth category was called "water and species-kinds". The participants mostly used such concepts as "cell" and "plant". Other concepts included "human", "animal", "root", "seed", "fruit" and "leaf". Furthermore, the words those were provided in this category by the prospective biology teachers but not included in this category as they were stated only once are as follows: fish and tree.

In accordance with the answers provided by the prospective biology teachers, the seventh category was called "water and environment". The concepts that were used by the participants included "soil" " $75 \%$ of the planet being water", "ecosystem" and "nature/environment". Furthermore, the words that were provided in this category by the prospective biology teachers but not included in this category as they were stated only once are as follows: agriculture and resources. In this category, the prospective biology teachers were observed not to have any meaning relationships.

In accordance with the answers provided by the prospective biology teachers, the eighth category was called "water pollution". The participants expressed the concepts "water pollution" and "decomposition". On the other hand, other words related to water pollution like "infiltration", "sewage", "washing-up", "laundry" and "toxic" were excluded owing to the fact that they had not been used more than once.

Furthermore, certain sample explanations by the prospective biology teachers as to water are provided below:

“Water occurs when $\mathrm{H}_{2}$ and $\mathrm{O}_{2}$ react with each other..." (P27).

“...It is an essential compound for life..." (P27)

“...water is life" (P29)

"...At least two liters of water should be consumed a day for a healthy life. Water plays a key role especially in the activities of kidneys" (P34).

"...food transmission has an important role in the volume of body liquids and maintenance of heat balance" (P43).

“...sea, lake and stream are sources of water” (P13).

"In plants, water is taken from roots and transported to leaves" (P30),

“...it is necessary for soil, environment and nature; that's why 75\% of the planet is water..." (P7).

"...what is important to me is the fact that water is being polluted. It is being polluted with different factors" (P20).

\subsection{The Results Determined Through Drawing-Writing Technique}

It is determined that the data collected through the drawing-writing technique to investigate prospective biology teachers' cognitive structures related to the concept of water fall into 9 categories in total. These can be listed as follows: The definition and chemical properties of water (52), The place and importance of water in life (51), Water resources and water cycle (38), Water and species-kinds (30), Water and metabolism (24), Water and environment (16), The physical properties of water (12), Use, awareness, culture and sustainability of water (10) and Water pollution (2). When the statements provided by the prospective biology teachers were analyzed, it was determined that they mostly used the terms, "vital activity" (17), "the continuation of life" (12), and "enzymes work" (9). However, it is seen that in this context, the findings of drawing are divided into 7 categories, and the findings of writing are into 9 categories (Table 2).

Table 2. The Findings of the Categories and Subcategories Obtained Through Drawing-Writing Technique Related To the Concept of Water

\begin{tabular}{llll}
\hline Main Category & Sub-category & Drawing (f) & Writing (f) \\
\hline & "H" & 6 & 4 \\
& "O" & 6 & 4 \\
& "water molecule" & 6 & 4 \\
1. The definition and chemical & "solver" & - & 4 \\
properties of water & "inorganic matter" & - & 3 \\
& "reaction" & 2 & 2 \\
& "chemical bond" & 3 & - \\
& "hydrogen bond" & 3 & - \\
& "explosive substance" & - & 3 \\
\hline
\end{tabular}


2. The place and importance of water in life

"substance"
Total
"vital activity"
"the continuation of life"
"70\% of human body comprised of water "
"need"
"the reason to live"
"drying wood"
"cleaning"
"living environment"
Total
"sea"
"river"
"rain"
"cloud"
"lake"
"streams"
"mountain"
"creeks"
"ocean"
Total
"tree/plant/the green plant"
"human"
"fish"
"bird"
"flower"
"animal"
"butterfly",
Total
"enzymes work"

3. Water resources and water cycle

4. Water and species-kinds

5. Water and metabolism

"enzymes work"

"photosynthesis"

"balancing body temperature"

"respiratory"

"growth"

"digestion"

"energy"

Total

"disrupted ecosystem/dried up lake"

" $75 \%$ of the world being water"

"drying river"

"global warming"

Total

"evaporation"

"melting"

7. The physical properties of water

"opposite poles meeting"

"beginning of physical events"

Total

"a glass of water/drinking

8. Use, awareness, water/pet bottle of water" culture and sustainability of water

"avoiding extravagancy"

"culture of water"

Total

"waste disposal"

9. Water pollution

\section{Total}


However, according to Table 2, the findings of the prospective biology teachers' drawings related to the concept of water fall into 7 categories. These can be listed as follows: "The definition and chemical properties of water" (25), "The place and importance of water in life" (7), "Water resources and water cycle" (28), "Water and species-kinds" (26), "Water and environment" (6), "The physical properties of water" (2), and "Use, awareness, culture and sustainability of water" (6). A review of the drawings of the prospective biology teachers concerning water indicates that they mainly drew figures of trees/plant/the green plant (9), river (7), $H(6), O(6)$, water molecule (6) and a glass of water/drinking water/plastic bottle (6). The examples of the figures provided by the prospective biology teachers related to the concept of water are provided in between Figure 4 and Figure 10.

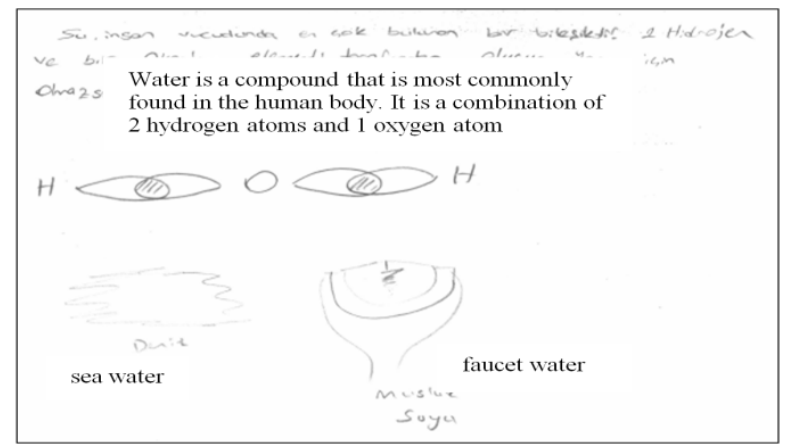

Figure 4. The Definition and Chemical Properties of Water (P10)

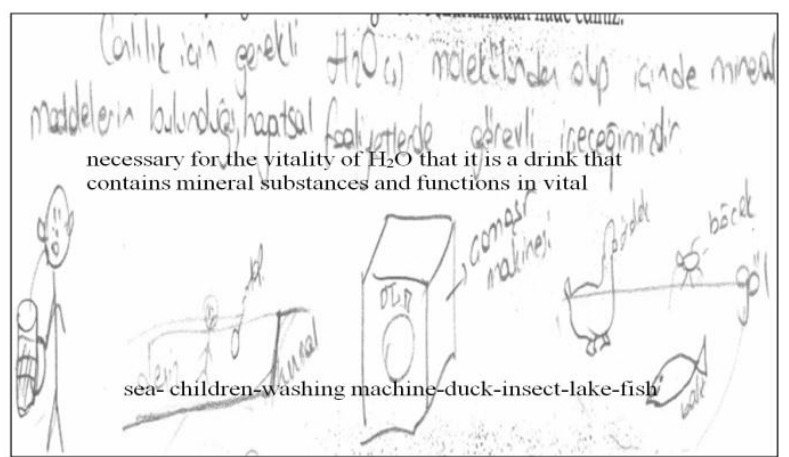

Figure 5. The Place and Importance of Water in Life (P31)

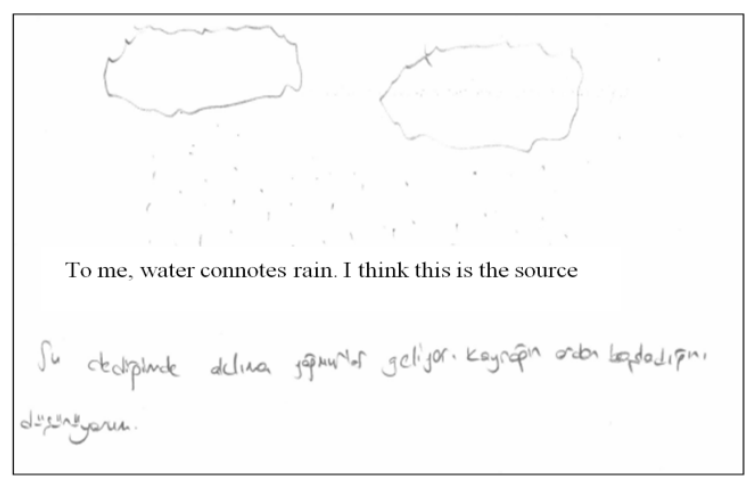

Figure 6. Water Resources and Water Cycle (P3) 


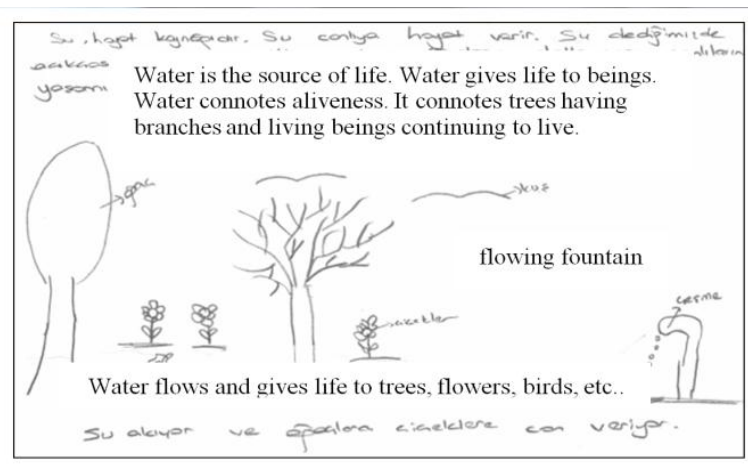

Figure 7. Water and Species-Kinds (P29)

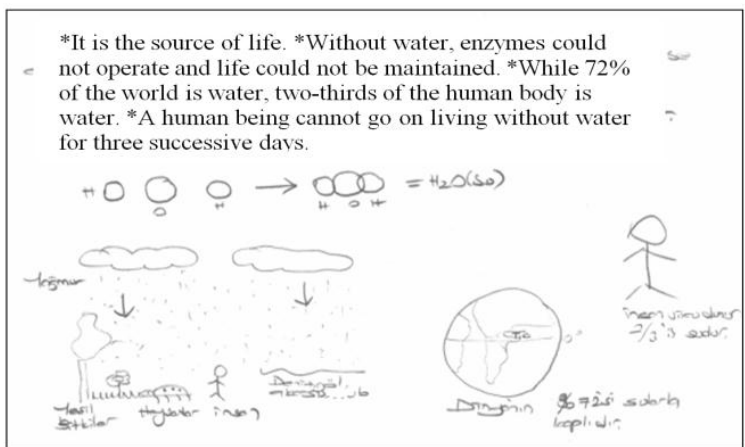

Figure 8. Water and Environment (P17)

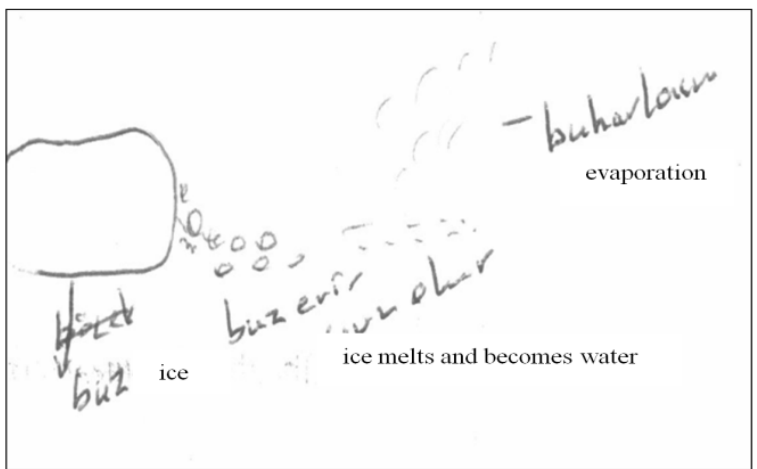

Figure 9. The Physical Properties of Water (P6)

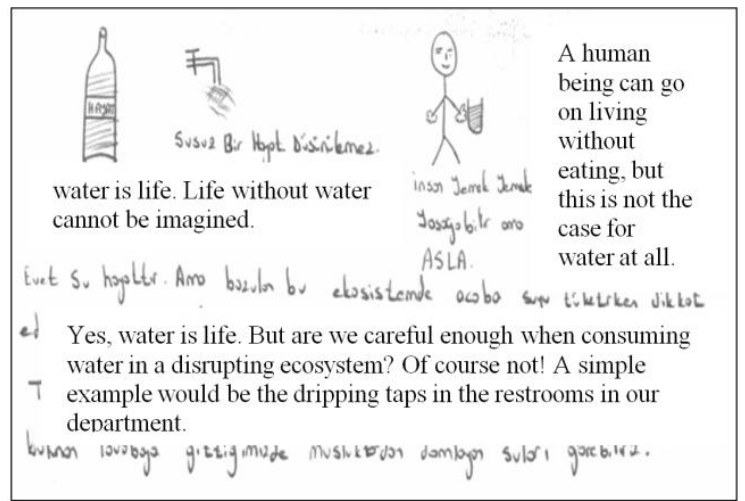

Figure 10. Use, Awareness, Culture and sustainability of water (P16) 
According to Table 2, the findings of the prospective biology teachers' writing related to the concept of water fall into 9 categories. These can be listed as follows: "The definition and chemical properties of water" (27), "The place and importance of water in life" (44), "Water resources and water cycle" (10), "Water and species-kinds" (4), "Water and metabolism" (10), "Water and environment" (10), "The physical properties of water" (10), "Use, awareness, culture and sustainability of water" (4) and "Water pollution" (2).

The following include some of the exemplary statements provided by the prospective biology teachers and the corresponding categories regarding the concept of water;

The examples determined in the category of "The definition and chemical properties of water";

"Water, which is comprised of a combination of 2 hydrogen atoms and 1 oxygen atom and source of life, is a compound with an exceptional place among other liquids..." (P9)

"Water is a compound that is most commonly found in the human body. It is a combination of 2 hydrogen atoms and 1 oxygen atom..." (P10)

The examples determined in the category of "The place and importance of water in life ";

"Water is vital for human life. It constitutes $70 \%$ of human body. It is a must for living things..." (P2)

"Water is important for humans to maintain their life.For living things to maintain their vital activities" (P19)

The examples determined in the category of "Water resources and water cycle ";

"To me, water connotes rain. I think this is the source." (P3)

"...Water is actually is within a constant cycle in which the same water has evaporated and then turned into water over and over for billions of years." (P4)

The examples determined in the category of "Water and species-kinds ";

“...no water, no life. Protoplasm, plants, animal and humans.” (P22)

“...humans, plants, animals etc. cannot live without water...” (P24)

The examples determined in the category of "Water and metabolism ";

"Water paves the way for metabolic activities of living beings..." (P1)

"...it is a must for the activities of enzymes, photosynthesis and respiration." (P2)

The examples determined in the category of "Water and environment ";

"Water covers $75 \%$ of the world and accounts for the life of beings..." (P11)

"Yes, water is life. But are we careful enough when consuming water in a disrupting environment?" (P16)

The examples determined in the category of "The physical properties of water ";

“A simultaneous combination of opposite poles, which results in a vital organ.” (P15)

“...water molecules with an angle of 104.5 degree, also properties of melting and boiling. If these bonds did not stick together in this way, water would always remain in the form of gas and would not be able to turn into solid or liquid. A freezing point of +4 degree enables lakes to be frozen from the upper surface. In this way, a living environment is provided for marine life." (P27)

The examples determined in the category of "Use, awareness, culture and sustainability of water ";

“...it is significant for cleaning. It ensures that microorganisms are cleaned and prevented from causing diseases. Microorganisms in water more often come to mind." (P2)

The examples determined in the category of "Water pollution ";

"We should treat waste" (P42)

"Waste should not pollute our drinking water; measures should be taken to prevent this" ( $\mathrm{P} 44)$

\subsection{The Results Determined Through the Semantic Differential Attitude Scale of the Concept of Water}

This study determined prospective biology teachers' conceptual structures about the concept of water as well their semantic attitudes towards this concept since affective dimension is very important in learning and success (Mayring \& Rhöneck, 2003; Mayring, 2009; Pekrun, Götz, Daniels, Stupnisky, \& Perry, 2010). Positive attitudes affect learning and success positively; on the other hand, negative attitudes affect these negatively. The descriptive values of the data collected on prospective biology teachers' attitudes towards the concept of water through the semantic differential attitude scale are provided in Table 3. 
Table 3. The Findings of the Descriptive Values of the Data Collected Through the Semantic Differential Attitude Scale of the Concept of Water

\begin{tabular}{|c|c|c|c|c|c|c|c|c|c|c|c|c|c|}
\hline \multirow[b]{2}{*}{ Semantic statements } & \multirow[b]{2}{*}{$\mathrm{N}$} & \multirow[b]{2}{*}{ Mean } & \multirow[b]{2}{*}{ SD } & \multicolumn{2}{|c|}{ Always } & \multicolumn{2}{|c|}{ Usually } & \multicolumn{2}{|c|}{ Partially } & \multicolumn{2}{|c|}{ Usually } & \multicolumn{2}{|c|}{ Always } \\
\hline & & & & $\mathrm{f}$ & $\%$ & $\mathrm{f}$ & $\%$ & $\mathrm{f}$ & $\%$ & $\mathrm{f}$ & $\%$ & $\mathrm{f}$ & $\%$ \\
\hline compulsory- not compulsory & 44 & 5.00 & .00 & 44 & 100 & - & - & - & - & - & - & - & - \\
\hline safe-not safe & 44 & 4.38 & .81 & 26 & 59.1 & 9 & 20.5 & 9 & 20.5 & - & - & - & - \\
\hline simple-complex & 44 & 3.22 & 1.15 & 8 & 18.2 & 8 & 18.2 & 17 & 38.6 & 8 & 18.2 & 3 & 6.8 \\
\hline relaxing-tiring & 44 & 4.56 & .72 & 31 & 70.5 & 7 & 15.9 & 6 & 13.6 & - & - & - & - \\
\hline valuable-worthless & 44 & 4.95 & .21 & 42 & 95.5 & 2 & 4.5 & - & - & - & - & - & - \\
\hline necessary- unnecessary & 44 & 4.90 & .29 & 40 & 90.9 & 4 & 9.1 & - & - & - & - & - & - \\
\hline useful- harmful & 44 & 4.81 & .49 & 38 & 86.4 & 4 & 9.1 & 2 & 4.5 & - & - & - & - \\
\hline clean- dirty & 44 & 3.93 & .99 & 18 & 40.9 & 7 & 15.9 & 17 & 38.6 & 2 & 4.5 & - & - \\
\hline important- trivial & 44 & 4.77 & .56 & 37 & 84.1 & 4 & 9.1 & 3 & 6.8 & - & - & - & - \\
\hline sustainable-unsustainable & 44 & 3.47 & .87 & 16 & 36.4 & 11 & 25 & 17 & 38.6 & - & - & - & - \\
\hline
\end{tabular}

As indicated in table 3, while it was determined considering the values of arithmetic average that prospective biology teachers considered the concept of water as always compulsory $(\bar{X}=5.00 ; 100 \%)$ in other words, positive attitudes, they adopted various attitudes determined as always safe ( $\bar{X}=4.38 ; 59.1 \%)$, partially neither simple nor complex ( $\bar{X}=3.22 ; 38.6 \%)$, always relaxing $(\bar{X}=4.56 ; 70.5 \%)$, always valuable $(\bar{X}=4.95 ; 95.5 \%)$, always necessary ( $\bar{X}=4.90 ; 90.9 \%)$, always useful ( $\bar{X}=4.81 ; 86.4 \%)$, always clean $(\bar{X}=3.93 ; 38.6 \%)$, always important $(\bar{X}=4.77 ; 84.1 \%)$ and partially neither sustainable nor unsustainable $(\bar{X}=3.97 ; 38.6 \%)$. These results indicate that the prospective teachers adopted different attitudes based on different adjectives. Each adjective was discussed and evaluated in its own context. In this vein, it was noticed that prospective teachers frequently considered the concept of water as compulsory, (100\%), valuable $(95.5 \%)$ and necessary $(90.9 \%)$. On the other hand, total attitude scores were calculated by averaging the responses for all 10 pairs (mean = 4.94). An overall above 3.5 was defined as a positive-always attitude, a score between 3.5 and 2.5 was considered neutral, and a score below 2.5 represented a negative attitude (Lohr \& Bummer, 1992). The prospective biology teachers' semantic attitudes toward water were found to be positive.

\subsection{The Model of the Prospective Biology Teachers' Cognitive Structures about Water}

Through using the free word-association test and the drawing-writing technique and evaluating prospective biology teachers' views on water, their cognitive structures were mapped. As indicated in this model, according to the analyses, while 8 categories were determined in the prospective biology teachers' cognitive structures related to water though the free word-associated test, 7 categories in the drawings and 9 categories in the writings were determined through the drawing-writing technique. As a result of the analysis of the data collected through the free-word association test and the drawing-writing technique, 9 categories were determined in total in the prospective biology teachers' cognitive structures related to water. On the other hand, when the categories obtained through the free word-association test and drawing-writing technique completed by the prospective biology teachers' were analyzed, 3 categories (The place and importance of water in life, The definition and chemical properties of water and Water and metabolism) appear to be as the most commonly and frequently emerging categories and their cognitive structures are framed within these categories (Model 1). On the other hand, prospective biology teachers' semantic attitudes toward water were found to be positive. 


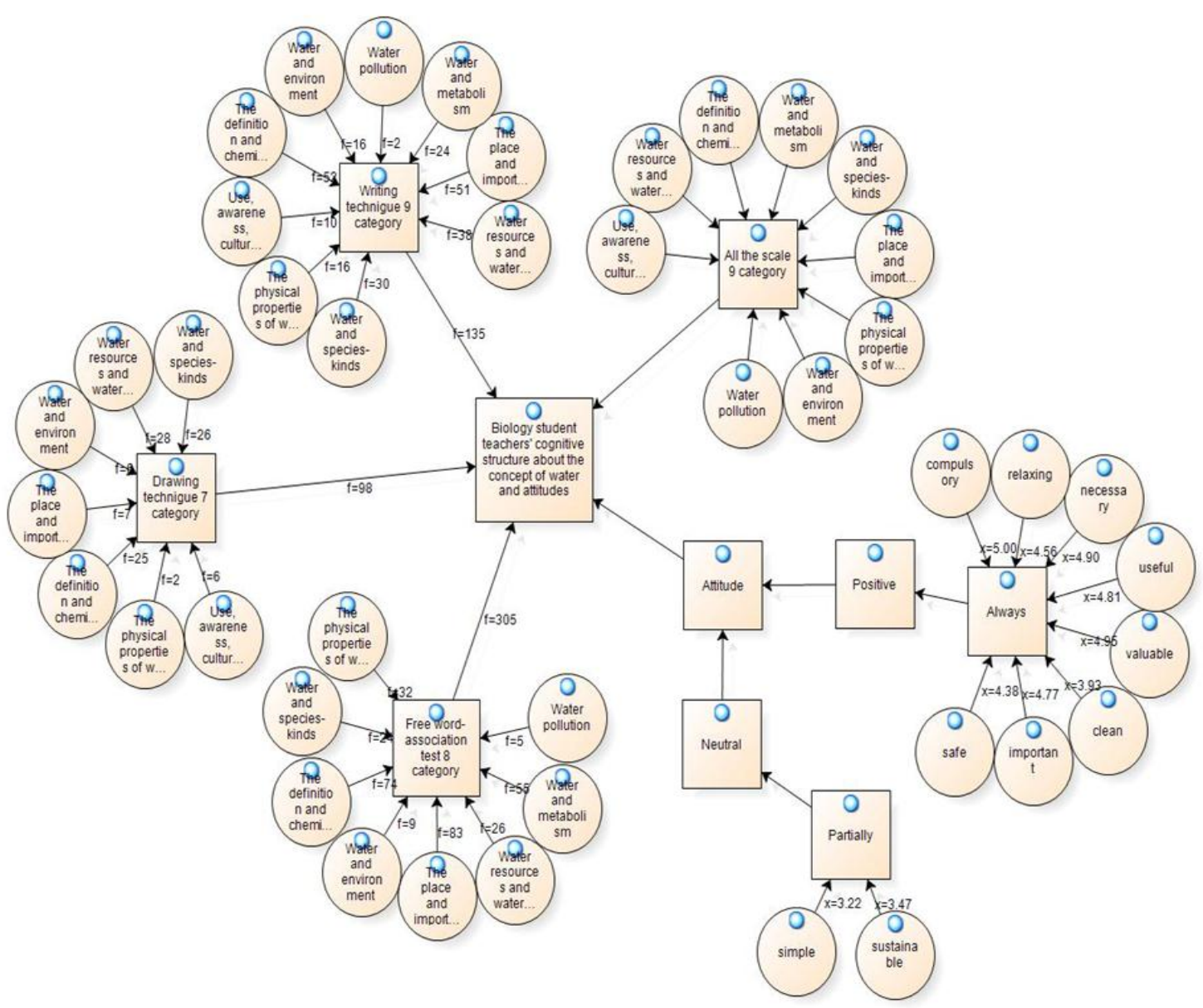

Model 1. The Model Created Through The Data Collected Via The Free Word-Association Test, The Drawing-Writing Technique, And The Semantic Differential Attitude Scale, "prospective Biology Teachers' Cognitive Structures Related To Water And Attitudes"

\subsection{The Prospective Teachers' Misconceptions about the Concept of Water}

One of the most important findings of the study is to determine that the prospective biology teachers had many misconceptions in each category of the concept of water. Constructivist epistemology endorses the view that eliciting what children already know and understand about scientific concepts is important, because prior knowledge affects future learning. Previous ideas should not be ignored if good learning outcomes are to be achieved (Scott, 1987; Selley, 1999) because they can form the basis of conceptual restructuring (Ausubel, 1968), so that meaningful learning can then take place. Therefore, it is essential to determine the participants' misconceptions about the concept of water. In this vein, the following include the participants' important misconceptions determined through the free word-association test and the drawing-writing technique:

The misconceptions determined in the category of "The definition and chemical properties of water";

An example from the free word-association test:

“"Water occurs when $\mathrm{H}_{2}$ and $\mathrm{O}_{2}$ react with each other..." (P27)

Examples from the drawing-writing technique:

"Water, which is comprised of a combination of 2 hydrogen atoms and 1 oxygen atom and source of life, is a compound with an exceptional place among other liquids..." (P9)

"Water is a compound that is most commonly found in the human body. It is a combination of 2 hydrogen atoms and 1 oxygen atom..." (P10)

"Water is an extinguishing substance formed because of the combination of an inflammable element and an explosive substance." (P23) 
The misconceptions determined in the category of "Water and metabolism";

An example from the free word- association test:

"Plants take in water through photosynthesis and release it into the atmosphere through their leaves." (P43)

Examples from the drawing-writing technique:

"Water paves the way for metabolic activities..." (P1)

"...enzymes are required for respiration; they are not compulsory, but important for photosynthesis." (P4)

The misconceptions determined in the category of "The physical properties of water ";

Examples from the free word- association test

"Ice melts; water evaporates." (P31)

"Water vapor merges into air in the form of bubbles." (P44)

The misconceptions determined in the category of "Water resources and water cycle";

An example from the free word- association test:

“...sea, lake and stream are sources of water." (P13)

Examples from the drawing-writing technique:

"To me, water connotes rain. I think this is the source." (P3)

"...Water is actually is within a constant cycle in which the same water has evaporated and then turned into water over and over for billions of years." (P4)

The misconceptions determined in the category of "Water and species-kinds";

An example from the free word-association test:

"In plants, water is taken in from roots and transported to leaves." (P30)

Examples from the drawing-writing technique:

“...no water, no life. Protoplasm, plants, animals, humans.” (P22)

“...humans, plants, animals etc. cannot live without water...” (P24)

The misconceptions determined in the category of "Water pollution";

Examples from the free word- association test:

"“....What is important to me is the fact that water is being polluted. It is being polluted with different factors." (P20)

"Waste should not pollute our drinking water; measures should be taken to prevent this." (P44)

The misconceptions revealed on the basis of the data on the participants obtained through the drawing-writing technique were generally in parallel with those revealed through the free word-association test. On the other hand, no misconceptions were identified on the part of the participants considering the place and importance of water in life, water and environment, use of water, awareness of water, culture of water, and sustainability of water.

\section{Discussion and Implications}

The aim of the current study is to investigate prospective biology teachers' cognitive structures related to "water" using the free word-association test and the drawing-writing technique and determine through which adjectives they express their attitudes towards the concept of water. Cognitive structures of prospective teachers about water are important given that these structures will help them to structure the nature of biology and biology related concepts. In the current study, through the data collected using different measurement instruments, the prospective biology teachers' positive and negative associations related to water and their cognitive structures were revealed. In this vein, as a result of the analysis of the data collected through the free word-association test, 8 categories were determined through the answer words provided by the prospective teachers, namely, "The place and importance of water in life", "The definition and chemical properties of water", "Water and metabolism", "The physical properties of water", "Water resources and water cycle", "Water and species-kinds", "Water and environment" and "Water pollution". 305 words were specified in total. As a result of the analysis of the data collected through the drawing-writing technique, 9 categories were determined through the answer words provided by the prospective teachers, namely, "The definition and chemical properties 
of water", "The place and importance of water in life", "Water resources and water cycle", "Water and species-kinds", "Water and metabolism”, "Water and environment”, "The physical properties of water", "Use, awareness, culture and sustainability of water" and "Water pollution". While in the drawing-writing technique, different categories, "Use, awareness, culture and sustainability of water" were determined, in the free word-association test. Moreover, in the drawing-writing technique, 9 categories were determined through analyzing the written statements, while through the drawings only 7 categories were determined. The categories that were not found in the drawings of the participants were "Water and metabolism" and "Water pollution". As a result of the analysis conducted through different measurement instruments while determining common categories, it was found that different categories also revealed. This result confirms that the study has achieved its aim and indicates that through using different measurement instruments, it is possible to obtain detailed data that both support and differ from one another.

In the overall analysis, it appeared that some of the prospective biology teachers did not write any meaningful sentence related to words, while some did not write any sentence. This might be attributed to the fact that they either did not want to write on purpose or did not write as they did not know. Most of the prospective biology teachers considered water in terms of its definition and chemical properties, which is generally the way prospective biology teachers are expected to form associations. However, this is not the desired and sufficient outcome. Considering the concepts provided by the prospective biology teachers, their cognitive structures related to the categories of the role and importance of water in life, the functions of water in living things and metabolism and the physical characteristics of water were found to be insufficient compared to the those related to the category of the definition of water and its chemical characteristics. Moreover, they less often preferred sources of water, the relationship between water and living beings and water pollution. Their statements revealed that their associations with defining water were insufficient, too. Although the concepts of the prospective biology teachers regarding "the definition of water and its chemical properties, the place and importance of water in life, functions of water in living beings and metabolism" were superficial, based on imperfect knowledge and not at the desirable level, their cognitive structures had conceptual validity. In the other studies conducted on university students, it was determined that students' cognitive structures were based on platitudes and imperfect knowledge. The results of this study are similar to those of the studies in the related literature.

One of the most important results of the study is to determine that the prospective biology teachers had many misconceptions in each category of the concept of water. Constructivist epistemology endorses the view that eliciting what children already know and understand about scientific concepts is important, because prior knowledge affects future learning. Previous ideas should not be ignored if good learning outcomes are to be achieved (Scott, 1987; Selley, 1999) because they can form the basis of conceptual restructuring (Ausubel, 1968), so that meaningful learning can then take place. Therefore, it is essential to determine the participants' misconceptions about the concept of water. In this vein, the following include the participants' important misconceptions determined through the free word-association test and the drawing-writing technique:

The misconceptions determined in the category of "The definition and chemical properties of water": An example: Water occurs when $\mathrm{H}_{2}$ and $\mathrm{O}_{2}$ react with each other..." (P27). It was determined that in the free word-association test and the drawing-writing technique, the prospective biology teachers' statements regarding the definition of water were incomplete and insufficient as the examples provided in these statements were related to hydrogen $(\mathrm{H})$, oxygen $(\mathrm{O})$, water molecule $\left(\mathrm{H}_{2} \mathrm{O}\right)$, and water considered as solvent. Similarly, it was reported that students' drawings of water (symbolic drawings) were not scientific and they could not understand it (Reis et al., 2002). Nyachwayaa et al. (2011) observed that the students in the study formulated water using the symbols of hydrogen $(\mathrm{H})$ and oxygen $(\mathrm{O})$. In addition, they used words like solvent and solution, and defined water as a solvent. In a study by Haidar and Abraham (1991), some of the students reported that water is a very good solvent by nature. Therefore, the findings of the present study seem to be supported by those in the literature.

The misconceptions determined in the category of "Water and metabolism"; Examples: "Plants take in water through photosynthesis and release it into the atmosphere through their leaves." (P43), "Water paves the way for metabolic activities..." (P1). The present study suggests that the significance of water for photosynthesis and respiration was not satisfactorily understood. Accordingly, it indicates that most of the participants did not take the necessity of water for photosynthesis into consideration in their cognitive structures. Several other studies have reported that prospective teachers do not refer to the effects of living beings on the water cycle or to photosynthesis in the carbon dioxide cycle (Celikler \& Topal, 2011; Hill, 1997).

The misconceptions determined in the category of "The physical properties of water "; Examples: "Ice melts; water evaporates." (P31), "Water vapor merges into air in the form of bubbles." (P44). It was revealed that 
some of the participants did not take into account evaporation in the water cycle or phases of water for living beings. They expressed the phases of water only in simple terms. The literature contains similar findings in this respect (Gooding \& Metz, 2011; Haland, 2010; Shepardson et al., 2009).

The misconceptions determined in the category of "Water resources and water cycle"; Examples: "...sea, lake and stream are sources of water." (P13), "To me, water connotes rain. I think this is the source." (P3). In addition to certain misconceptions, the participants had unrelated and simple conceptual structures concerning water. Furthermore, it was observed that they had not touched on underground waters, one of the sources of water. Subjects associated with the water cycle are commonly found difficult by students (Ben-Zvi Assaraf \& Orion, 2010a). Primary school, secondary school and high school students only focus on the water cycle between the atmosphere and land surface (Ben-Zvi Assaraf et al., 2012).

The misconceptions determined in the category of "Water and species-kinds"; Examples: "In plants, water is taken in from roots and transported to leaves." (P30), “...humans, plants, animals etc. cannot live without water..." (P24). Although the participants emphasized the significance of water for living beings, they did not attract attention to its place in the water cycle. Thus, they can be argued to have imperfect knowledge. Accordingly, the literature includes many findings on the fact that participants have a number of misconceptions. The students were found to insufficiently understand the link between plants and underground waters (Ben-Zvi Assaraf et al., 2012), not to understand the fact that water is absorbed by roots and to think that water is taken in through leaves (Levins \& Pegg, 1993).

The misconceptions determined in the category of "Water pollution"; Examples: “....What is important to me is the fact that water is being polluted. It is being polluted with different factors." (P20), "We should treat waste." (P42). The participants did not specify the measures that should be taken to prevent water pollution. Therefore, they can be argued to have imperfect and insufficient knowledge. The literature contains similar findings in this respect (Boyes et al., 1999; Brody, 1994).

The misconceptions revealed on the basis of the data on the participants obtained through the drawing-writing technique were generally in parallel with those revealed through the free word-association test. On the other hand, no misconceptions were identified on the part of the participants considering the place and importance of water in life, water and environment, use of water, awareness of water, culture of water, and sustainability of water. An overall view of the drawings of the prospective biology teachers suggests that they mostly defined water using the symbols $\mathrm{H}$ and $\mathrm{O}$. Some of them connected them specifying an angle of 104.5 degree between them; however, they did not present them in the form of molecular bonds. Similarly, Reis et al. (2002) reported that students' drawings of water (symbolic drawings) were not scientific, whereas Nyachwayaa et al. (2011) found that they formulated water using the symbols $\mathrm{H}$ and $\mathrm{O}$. In addition to being in parallel with those of primary school, secondary school and high school students, conceptual structures of prospective biology teachers also resemble those of other prospective teachers (Celikler \& Topal, 2011). Considering the current study, it can be stated that the prospective Biology teachers' conceptual structures are not sufficient. Accordingly, scientific facts should be taught regarding this issue since there are many differences between the concepts used in daily life and scientific concepts (Bandiera, 2007). It is important for prospective biology teachers to obtain the necessary scientific facts about this issue for their success in their profession considering that they will be teachers of biology.

While the associations determined in the study reflect students' platitudes (image), this situation is discussed in other studies conducted using different concepts and terms. It can be put forward that prospective biology teachers' cognitive structures about water are superficial. The current study revealed that of the 9 categories determined through both the free word-association test and the drawing-writing technique, 3 appeared as the dominant categories, namely, the place and importance of water in life, the definition and chemical properties of water and water and metabolism. The prospective biology teachers' levels of knowledge were found to be sufficient in these categories; however, it was also determined that they had some misconceptions about the concept of water.

However, as is known, the concept of water is the most commonly used concept in many disciplines related to each other. It was also noticed that the prospective biology teachers had some misconceptions and alternative concepts in the majority of the categories determined as related to the concept of water. Alternative concepts and misconceptions are due to the fact that the connections between concepts cannot be structured completely in individuals' minds while they are learning concepts. Unless educators explain the basic characteristics of a concept and the differences between this concept and similar concepts precisely, students at various levels will have misconceptions. Before defining a concept, educators should first explain it reflecting its basic 
characteristics and help understand its relationship with other concepts (Wandersee, Mintzes, \& Novak, 1994). Thus, educators can prevent students from having misconceptions.

Moreover, according to the results of this study, it was determined that prospective biology teachers did not have the expected level of biological literacy; because the expressions given to the writing technique revealed that prospective biology teachers could not go beyond just a few quite stereotyped focused only on water definitions. These students, who will be biology teachers when they graduate, were thought to be not equipped with the necessary knowledge. Future biology teachers should develop subjective interpretations of the importance of biology knowledge, think creatively, ask different questions and thoroughly evaluate the information. Thus, teaching concepts and conceptual learning should be given great importance.

According to the results of the current study, it was determined that although the prospective biology teachers could make relationships in some of the main categories, though not sufficient; however failed to do so in some of the categories, and had some important misconceptions. Therefore, the conceptual biological literacy that prospective Biology teachers were expected to have could not be determined (Uno \& Bybee, 1994). As stated by Kurt, Kaya, Ates, \& Kilic, (2009), it was determined that the vast majority of the prospective biology teachers did not have biological literacy. It can be also stated that the prospective biology teachers' dates did not have biological literacy. The prospective biology teachers' semantic attitudes toward water were found to be positive. The participants of the study conducted by Praneetham and Thathong (2012) associated water, which is in alignment with the current study.

Consequently, one of the most important factors that affect learning is the existing knowledge and conceptual structures. Individuals cannot attach meanings to ideas that do not correspond to scientific facts in these conceptual structures. If the concepts learned are not meaningfully acquired and structured, learning gets more difficult, leading to misconceptions and inaccurate information. Therefore, it is necessary to determine students' conceptual structures, inaccurate and incomplete information, and concepts before starting to teach. Teaching and learning should be planned through suitable strategies, methods, and techniques. Thus, students can code meaningfully new concepts and information in their minds, and create accurate correlation between these concepts and information, which leads to more meaningful and permanent learning. In some studies (Ben-Zvi Assaraf, 2012; Cin, 2004; Dickerson \& Dawkins, 2004; Nyachwayaa et al., 2011) data were collected on the concept of water using various measurement tools. Data collection instruments such as Likert-type scales, drawing, drawing-writing, pictures, and photographs were used in these studies. The current study conducted through using the free word-association test, the drawing-writing technique, and the scale of semantic differential attitudes can be re-conducted with students and teachers using the interview technique in addition to different measurement techniques, which is believed to contribute to the literature.

\section{References}

Ad, V. N. K., \& Demirci, N. (2012). Prospective teachers' levels of associating environmental problems with science fields and thermodynamics laws. Ahi Evran University Journal of Kirsehir Educational Faculty, 13(3), 19-46

Agelidou, E., Balafoutas, G., \& Gialamas, V. (2001). Interpreting how third grade junior high school students represent water. International Journal of Education and Information, 20(1), 19-36.

Aitken, C. McMahon, T. A. Wearing, A. J., \& Finlayson, B. L. (1993). Residential water use: Predicting and reducing consumption. Journal of Applied Social Psychology, 24(2), 136-158. https://doi.org/10.1111/j.1559-1816.1994.tb00562.x

Akin, G., Gulec, E., Sagir, M., Gultekin, T., \& Bektas Y. (2005).Aging and anti-aging environmental factors. III. National congress of old age, 16-19 November, 127-137, Izmir, Turkey.

Akin, M., \& Akin, G. (2007). Significance of water, water potential of Turkey, catchments and water pollution. Ankara University, Faculty of Language, History and Geography Journal of Anthropology, 47(2), 105-118.

Alerby, E. (2000). A way of visualizing children's and young people's thoughts about the environment: A study of drawings. Environmental Education Research, 6(3), 205-222. https://doi.org/10.1080/13504620050076713

Ali, I. (1991). How do English pupils understand pollution?. Environmental Education and Information, 10(4), 203-220.

Anderson, J. E. (1987). Assessing affective characteristics in the schools. Reston, Va: Reston Publishers.

Anderson, L. W. (1988). Attitude measurement: Attitudes and their measurement. In J. P. Keeves (Eds.). Educational research methodology and measurement: An international handbook. New York: Pergamon 
Press.

Anderson, C. W., Sheldon, T. H., \& DuBay, J. (1990). The effect of instruction on college nonmajors' conceptions of photosynthesis and respiration. Journal of Research in Science Teaching, 27(8), 761-776. https://doi.org/10.1002/tea.3660270806

Anderson, B. A. (2010). Water pollution awareness and drinking water treatment in rural South Africa. Amman American Journal of Applied Science, 2010, 1123-1128. https://doi.org/10.3844/ajassp.2010.1123-1128

Ausubel, D. P. (1968). Educational psychology: A cognitive view. New York: Holt, Rinehart and Winston.

Atasoy, B., Kadayifci, H., \& Akkus, H. (2007). Revealing the creative ideas through students' drawings and statements. Journal of Turkish Educational Sciences, 5(4), 679-700.

Ayas, A., \& Ozmen, H. (2002). A study of students' level of understanding of the particulate nature of matter at secondary school. Bogazici University Journal of Education, 19(2), 45-60.

Backett-Milburn, K., \& McKie, L. (1999). A critical appraisal of the draw and write technique. Health Education Research Theory \& Practice, 14(3), 387-398. http://dx.doi.org/10.1093/her/14.3.387

Bagozzi, R. P., \& Burnkrant, R. E. (1985). Attitude organization and attitude-behavior relation: A reply to Dillon and Kumar. Journal of Personality and Social Psychology, 49(1), 47-57. http://dx.doi.org/10.1037/0022-3514.49.1.47

Bahar, M., Johnstone, A. H., \& Sutcliffe, R. G. (1999). Investigation of students' cognitive structure in elementary genetics through word association tests. Journal of Biological Education, 33(3), 134-141. http://dx.doi.org/10.1080/00219266.1999.9655653 .

Ballweg, J. A. (1972). Measuring attitudes toward water use priorities. Water Resources Research Center Virginia Polytechnic Institute and State University Blacksburg, Va.

Bandiera, M. (2007). Micro-organisms: Everyday knowledge predates and contrasts with school knowledge. Contributions from Science Education Research, 213-224.

Bar, V., \& Galili, I. (1994). Stages of children's views about evaporation. International Journal of Science Education, 16(2), 157-174. https://doi.org/10.1080/0950069940160205

Bar, V., \& Travis, A. (1991). Children's views concerning phase changes. Journal of Research in Science Teaching, 28, 363-382. https://doi.org/10.1002/tea.3660280409

Barman, C. R., Stein, M., McNair, S., \& Barman, N. S. (2006). Students' ideas about plants \& plant growth. The American Biology Teacher, 68(2), 73-79. https://doi.org/10.1662/0002-7685(2006)068[0073:SIAPPG]2.0.CO;2

Ben-Zvi, A. O., \& Orion, N. (2005a). Development of system thinking skills in the context of earth systems education. Journal of Research in Science Teaching, 42(5), 518-560. https://doi.org/10.1002/tea.20061

Ben-Zvi, A. O., \& Orion, N. (2005b). A study of junior high students' perceptions of the water cycle. Journal of Geoscience Education, 53(4), 366-373. https://doi.org/10.5408/1089-9995-53.4.366

Ben-Zvi, A. O., \& Orion, N. (2010a). How can elementary school students deal with complex systems? Journal of Research in Science Teaching, 47(5), 540-563. https://doi.org/10.1002/tea.20351

Ben-Zvi, A. O., \& Orion, N. (2010b). Four case studies, six years later: Developing system thinking skills in junior high school and sustaining them over time. Journal of Research in Science Teaching, 47(10), 1253-1280. https://doi.org/10.1002/tea.20383

Ben-Zvi, A. O., Eshach, H., Orion, N., \& Alamour, Y. (2012). Cultural differences and students' spontaneous models of the water cycle: A case study of Jewish and Bedouin children in Israel. Cultural Studies of Science Education, 7(2), 451-477. https://doi.org/10.1007/s11422-012-9391-5

Bloom, S. B. (1979). Human characteristics and school learning. New York: McGraw-Hill.

Bohner, G., \& Wanke, M. (2002). Attitude and attitude change. New York: Psychology Press.

Boo, H. K. (2006). Primary science assessment item setters' misconceptions concerning the state changes of water. Asia-Pacific Forum on Science Learning and Teaching, 7(1), 1-15.

Boyes, E., Stanisstreet, M., \& Spiliotopoulou-Papantoniou, V. (1999). The ideas of Greek high school students about the "Ozone layer". Science Education, 83(6), 724-737.

Brody, M. (1991). Understanding of pollution among 4th, 8th, and 11th grade students. International Journal of 
Science Education, 22(2), 24-33. https://doi.org/10.1080/00958964.1991.9943051

Brody, M. (1994). Student science knowledge related to ecological crisis. International Journal of Science Education, 16(4), 421-435. https://doi.org/10.1080/0950069940160404

Celikler, D., \& Topal, N. (2011). Identification of the knowledge of prospective science teachers about carbon dioxide and water cycle through drawings. Journal of Educational and Instructional Studies in the World, $1(1), 72-79$.

Cheam, J. (2012, February 2). More Singaporeans care about climate change. Straits Time, 3.

Cin, M. (2004). An investigation of the conceptions of sea among primary school children. Educational Sciences: Theory \& Practice, 4(1), 18-23.

Costu, B., Ayas, A., Niaz, M., Unal, S., \& Calik, M. (2007). Facilitating conceptual change in students' understanding of boiling concept. Journal of Science Education and Technology, 16(6), 524-536. https://doi.org/10.1007/s10956-007-9079-x

Damanhouri, M. S., Al-Saleem, B. A., \& AL-Ali, Y. Y. (2012). Level of water awareness at some Jordanian Universities Student's. Journal of Social Sciences, 8(3), 454-458. https://doi.org/10.3844/jssp.2012.454.458

Daskolia, M., Flogaitis, E., \& Papageorgiou, E. (2006). Kindergarten teachers' conceptual framework on the ozone layer depletion. Exploring the associative meanings of a global environmental issue. Journal of Science Education and Technology, 15(2), 168-178. http://dx.doi.org/10.1007/s10956-006-9004-8

Dickerson, D., \& Dawkins, K. (2004). Eighth grade students' understandings of groundwater. Journal of Geoscience Education, 52(2), 178-181.

Dickerson, D., Callahan, T. J., Sickle, M. V., \& Hay, G. (2005). Students' conceptions of scale regarding groundwater. Journal of Geoscience Education, 53(4), 374-380. https://doi.org/10.5408/1089-9995-53.4.374

Dove, J. E., Everett, L. A., \& Preece, P. F. W. (1999). Exploring a hydrological concept through children's drawings. International Journal of Science Education, 21(5), 485-497. https://doi.org/10.1080/095006999290534

Duda, M. D. (Eds.). (2005). Americans' knowledge of and attitudes toward water and water-related issues. Responsive Management National Office. Harrisonburg, VA. www.responsivemanagement.com

Ewing, M. S., \& Mills, T. J. (2004). Water literacy in college freshmen: Could imagery strategy improve understanding? The Journal of Environmental Education, 25(4), 36-40. https://doi.org/10.1080/00958964.1994.9941963

Finson, K. D., Beaver, J. B., \& Cramond, B. L. (1995). Development and field tests of a checklist for draw - a scientist test. School Science and Mathematics, 95(4), 195-205. https://doi.org/10.1111/j.1949-8594.1995.tb15762.x

Fishbein, M., \& Ajzen, I. (1975). Belief, attitude, intention and behavior: An introduction to theory and research. Reading, MA: Addison-Wesley.

Fisher, K. M., Williams, K. S., \& Lineback, J. E. (2011). Osmosis and diffusion conceptual assessment. Life Sciences Education, 10(4), 418-429. https://doi.org/10.1187/cbe.11-04-0038

Garland, H. D. (2005). Evidence of witnessed community violence in children's drawings. Dissertation abstracts international: Section B: The sciences and engineering, 65(12-B), 6650.

Gilbertson, M., Hurlimann, A., \& Dolnicar, S. (2011). Does water context influence behavior and attitudes to water conservation? Australasian Journal of Environmental Management, 18(1), 47-60. http://dx.doi.org/10.1080/14486563.2011.566160

Gilg, A., \& Barr, S. (2006). Behavioral attitudes towards water saving? Evidence from a study of environmental actions. Ecological Economics, 57(3), 400-414. http://dx.doi.org/10.1016/j.ecolecon.2005.04.010

Glesne, C., \& Peshkin, A. (1992). Becoming qualitative researchers an introduction. London: Longman Group Ltd.

Gooding, J., \& Metz, B. (2011). From misconceptions to conceptual change: Tips for identifying and overcoming students misconceptions. The Science Teacher, 78(4), 34-37.

Gussarsky, E., \& Gorodetsky, M. (1990). On the concept "chemical equilibrium: The associative framework. 
Journal of Research in Science Teaching, 27(3), 197-204. https://doi.org/10.1002/tea.3660270303

Haidar, H. A., \& Abraham, R. M. (1991). A comparison of applied and theoretical knowledge of concept based on the particulate nature of matter. Journal of Research in Science Teaching, 28(10), 919-938. https://doi.org/10.1002/tea.3660281004

Haland, B. (2010). Student teacher conceptions of matter and substances-evaporation and dew formation. Nordina, 6(2), 109-124. http://dx.doi.org/10.5617/nordina.251

Hayes, D., Symington, D., \& Martin, M. (1994). Drawing during science activity in the primary school. International Journal of Science Education, 16(3), 265-277. https://doi.org/10.1080/0950069940160302

Hatzinikita, V., \& Koulaidis, V. (1997). Pupils' ideas on conservation during changes in the state of water. Research in Science \& Technological Education, 15(1), 53-70. https://doi.org/10.1080/0263514970150104

Hill, D. G. (1997). Conceptual change through the use of student-generated analogies of photosynthesis and respiration by college nonscience majors. Unpublished $\mathrm{PhD}$ thesis. Georgia University, Athens, Georgia, USA.

Hovardas, T., \& Korfiatis, K. J. (2006). Word associations as a tool for assessing conceptual change in science education. Learning and Instruction, 16(5), 416-432. https://doi.org/10.1016/j.learninstruc.2006.09.003

Hurlimann, A., \& Dolnicar, S. (2010). Australians' water conservation behaviours and attitudes. Australian Journal of Water Resources, 14(1), 43-53.

Hruschka, D. J., Schwartz, D., St.John, D. C., Picone-Decaro, E., Jenkins, R. A., \& Carey, J. W. (2004). Reliability in coding open-ended data: Lessons learned from HIV behavioral research. Field Methods, 16(3), 307-331. http://dx.doi.org/10.1177/1525822X04266540

Johnson, P. (1998). Children's understanding of changes of state involving the gas state, Part 2: Evaporation and condensation below boiling point. International Journal of Science Education, 20(6), 695-709. https://doi.org/10.1080/0950069980200607

Kagitcibasi, C. (2010). Human and humans: An introduction to social psychology. Istanbul: Evrim Publishing.

Knight, S. L., Nolan, J., Lloyd, G., Arbaugh, F., Edmondson, J., \& Whitney, A. (2013). Quality teacher education research:How do we know it when we see it? Journal of Teacher Education, 64(2), 114-116. https://doi.org/10.1177/002248711246994

Koray, O., Akyaz, N., \& Koksal, M. S. (2007). The observed concept errors about the "resolution" subject in the daily life events of the Lycee students. Kastamonu Education Journal, 15(1), 241-250.

Kose, S. (2008). Diagnosing Student Misconceptions: Using Drawings as a Research Method. World Applied Sciences Journal, 3(2), 283-293.

Koseoglu, F., \& Bayir, E. (2011). Examining cognitive structures of chemistry teacher candidates about gravimetric analysis through word association test method. Trakya University Journal of Education Faculty, l(1), 107-125.

Kostova, Z., \& Radoynovska, B. (2008). Word association test for studying conceptual structures of teachers and students. Bulgarian Journal of Science and Education Policy, 2(2), 209-231.

Kostova, Z., \& Radoynovska, B. (2010). Motivating students' learning using word association test and concept maps. Bulgarian Journal of Science and Education Policy, 4(1), 62-98.

Kurt, H., Kaya, B., Ates, A., \& Kilic, S. (2009). The biological literacy of biology teacher candidates. Selcuk University Journal of Ahmet Kelesoglu Education Faculty, 27, 17-30.

Kurt, H. (2013a). Determining Biology Teacher Candidates' Conceptual Structures about Energy and Attitudes towards Energy. Journal of Baltic Science Education, 12(4), 399-423.

Kurt, H. (2013b). Turkish Student Biology Teachers' Conceptual Structures and Semantic Attitudes Towards Microbes. Journal of Baltic Science Education, 12 (5), 608-639.

Lee, T. (2009). A survey of public perceptions and attitudes towards water in Wheatland County. Miistakis Institute, University of Calgary, Calgary, AB. Retrieved from http://www.rockies.ca

Lenton, G. M., \& McNeil, J. (1993). Primary school teachers' understanding of biological concepts: Selected research findings. British Journal of in-Service Education, 19(2), 27-34.

Levins, L., \& Pegg, J. (1993). Students' understanding of concepts related to plant growth. Research in Science 
Education, 23, 165-173.

Levin, I., \& Bus, A. G. (2003). How is emergent writing based on drawing? Analyses of children's products and their sorting by children and mothers. Developmental Psychology, 39(5), 891-905. http://dx.doi.org/10.1037/0012-1649.39.5.891

Lohr, V. I., \& Bummer, L. H. (1992). Assessing and influencing attitudes toward water-conserving landscape. HortTechnology, 2(2), 253-256.

Martin, P. R. (2001). Prospected teachers' ideas about the relationships between concepts describing the composition of matter. International Journal of Science Education, 23(4), 353-371. https://doi.org/10.1080/095006901300069084

Marvasti, A. B. (2004). Qualitative research in sociology. London: Sage Publications Ltd.

Mayring, P., \& Rhöneck, C. (2003). Learning Emotions. The influence of affective factors on classroom learning. Peter Lang, Frankfurt, London.

Mayring, P. (2009). Freude und Glück. In V. Brandstätter \& J.H. Otto (Hrsg.). Handbuch der allgemeinen psychologie - Motivation und emotion (pp. 585-595). Göttingen Hogrefe.

McDaniels, T. L., Axelrod, L. J., \& Cavanagh, N. (1998). Public perceptions regarding water quality and attitudes toward water conservation in the lower Fraser Basin. Water Resources Research, 34(5), 1299-1306. https://doi.org/10.1029/98WR00436

McPeak, V. L. (2009). Improving high school students' knowledge of and attitudes about water quality, treatment and conservation. Unpublished Master Thesis, Michigan Technological University.

Miles, M. B., \& Huberman, A. M. (1994). Qualitative data analysis: An expanded sourcebook (2nd ed.). Thousand Oaks, California: SAGE. Morahan- Martin.

Mohapatra, A. K., \& Bhadauria, M. (2009). An investigation of Indian secondary level students' alternative conceptions of water pollution. Indian Journal of Science and Technology, 2(11), 72-76.

Muller, D. J. (1986). Measuring social attitudes: A handbook for researchers and practitioners. New York: Teachers College Press.

Nyachwayaa, J. M., Mohameda, A-R., Roehriga, G. H. Woodb, N. B., Kernc, A. L., \& Schneiderd, J. L. (2011). The development of an open-ended drawing tool: an alternative diagnostic tool for assessing students' understanding of the particulate nature of matter. Chemistry Education Research and Practice, 12(2), 121-132. http://dx.doi.org/10.1039/c1rp90017j

Odom, A. L., \& Barrow, L. H. (2007). High school biology students' knowledge and certainty about diffusion and osmosis concepts. School Science and Mathematics, 107(3), 94-101. https://doi.org/10.1111/j.1949-8594.2007.tb17775.x

Osborne, R. J., \& Cosgrove, M. M. (1983). Children's conceptions of the changes of state of water. Journal of Research in Science Teaching, 20(9), 825-838. https://doi.org/10.1002/tea.3660200905

Ozatli, N. S., \& Bahar, M. (2010). Revealing students' cognitive structures regarding excretory system by new techniques. The Journal of Abant Izzet Baysal University, 10(2), 9-26.

Patton, M. Q. (2002). Qualitative research \& evaluation methods (3rd ed.). London: Sage Publications, Inc.

Pekrun, R., Götz, T., Daniels, L. M., Stupnisky, R. H., \& Perry, R. P. (2010). Boredom in achievement settings: Exploring control-value antecedents and performance outcomes of a neglected emotion. Journal of Educational Psychology, 102(3), 531-549. http://dx.doi.org/10.1037/a0019243

Poggenpoel, M., \& Myburgh, C. (2003). The researcher as research instrument in educational research: A possible threat to trustworthiness?. Education, 124(2), 418-421.

Praneetham, C., \& Thathong, K. (2012). Attitudes and behaviors of high school students in Vientiane, Lao People's democratic republic, towards the environment. European Journal of Social Sciences, 35(1), 5-12

Pridmore, P., \& Bendelow, G. (1995). Images of health: Exploring beliefs of children using the 'draw-and-write' technique. Health Education Journal, 54(4), 473-488. https://doi.org/10.1177/001789699505400410

Reinfried, S., Tempelmann, S., \& Aeschbacher, U. (2012). Addressing secondary students' naive ideas about freshwater springs in order to develop an instructional tool to promote conceptual reconstruction. Hydrology and Earth System Sciences, 9(2), 1589-1617. http://doi:10.5194/hessd-9-1589-2012 
Reiss, M. J., Tunnicliffe, S. D., Andersen, A. M., Bartoszeck, A., Carvalho, G. S., Chen, S.-Y., \& Jarman, R., et al. (2002). An international study of young peoples' drawings of what is inside themselves. Journal of Biological Education, 36(2), 58-64. http://dx.doi.org/10.1080/00219266.2002.9655802

Rennie L. J., \& Jarvis, T. (1995). English and Australian children's perceptions about technology. Research Science Technology Education, 13(1), 37-52. http://doi:10.1080/0263514950130104

Roberts, P., Priest, H., \& Traynor, M. (2006). Reliability and validity in research. Nursing Standard, 20(44), 41-45. http://doi:10.7748/ns2006.07.20.44.41.c6560

Rundgren, C-J., Rundgren, S-N. C., \& Schönborn, K. J. (2010). Students' conceptions of water transport. Journal of Biological Education, 44(3), 129-135. https://doi.org/10.1080/00219266.2010.9656209

Russel, J., \& Hollander, S. (1975). A biology attitude scale. The American Biology Teacher, 37(5), 270-273. http://doi: $10.2307 / 4445229$

Sari, H-N., Kärkkäinen, S., \& Keinonen, T. (2011). Primary school pupils' perceptions of water in the context of STS study approach. International Journal of Environmental \& Science Education, 6(4), 321-339

Sato, M., \& James, P. (1999)."Nature" and "Environment" as perceived by university students and their supervisors. International Journal of Environmental Education and Information, 18(2), 165-172.

Scott, P. (1987). A constructivist view of learning and teaching in science. Leeds: Centre for Studies in Science and Mathematics Education, University of Leeds.

Selley, N. (1999). The art of constructivist teaching in the primary school. London: David Fulton.

Seloni, S. R. (2005). Elimination of misconceptions that science teaching with project-based learning. Unpublished Master Thesis. Istanbul: Marmara University.

Shenton, A. (2004). Strategies for ensuring trustworthiness in qualitative research projects. Education for Information, 22, 63-75. http://doi:10.3233/EFI-2004-22201

Shepardson, D. P., Wee, B., Priddy, M., Schellenberger, L., \& Harbor, J. (2007). What is a watershed? Implications of student conceptions for environmental science education and the National Science Education Standards. Science Education, 91(4), 554-578. https://doi.org/10.1002/sce.20206

Shepardson, D. P., Wee, B., Priddy, M., Schellenberger, L., \& Harbor, J. (2009). Water transformation and storage in the mountains and at the coast: Midwest students' disconnected conceptions of the hydrologic cycle. International Journal of Science Education, 31(11), 1447-1471. https://doi.org/10.1080/09500690802061709

Songer, C. J., \& Mintzes, J. J. (1994). Understanding cellular respiration: An analysis of conceptual change in college biology. Journal of Research in Science Teaching, 31(6), 621-637. https://doi.org/10.1002/tea.3660310605

Stavridou, H., \& Marinopoulos, D. (2001). Water and air pollution: Primary students' conceptions about "Itineraries" and interactions of substances. Chemistry Education: Research and Practice in Europe, 2(1), 31-41. http://doi:10.1039/A9RP90035G

Taiwo, A. A., Ray, H., Motswiti, M. J., \& Masene, R. (1999). Perceptions of the water cycle among primary school children in Botswana. International Journal of Science Education, 21, 413-429.

Tatar, N., \& Koray, O. C. (2005). Determination of the misconceptions of the 8th grade students in primary school about "Genetics" unit. Kastamonu Education Journal, 13(2), 415-426.

Tekkaya, C., \& Balci, S. (2003). Determined students' misconceptions photosynthesis and respiration. Journal of Hacettepe University Education Faculty, 24, 101-107. https://doi.org/10.1016/j.sbspro.2010.03.474

Thayer, R. L., Jr. (1982). Public response to water-conserving landscapes. HortScience, 17(4), 562-565.

Thompson, F., \& Logue, S. (2006). An exploration of common student misconceptions in science. International Education Journal, 7(4), 553-559.

Tytler, R. (2000). A comparison of year 1 and year 6 students' conceptions of evaporation and condensation: dimensions of conceptual progression. International Journal of Science Education, 22(5), 447-467 https://doi.org/10.1080/095006900289723 .

Uno, E. G., \& Bybee, W. R. (1994). Understanding the dimensions of biological literacy. BioScience, 44(8), 553-557. 
Wandersee, J. H., Mintzes, J. J., \& Novak, J. D. (1994). Research on alternative conceptions in science. In D. L. Gabel (Ed.). Handbook of research on science teaching and learning (pp. 177-210). NY: Macmillan.

Verplanken, B., \& Hofstee, G. (1998). Accessibility of affect versus cognitive components of attitudes. European Journal of Social Psychology, 28, 23-35.

https://doi.org/10.1002/(SICI)1099-0992(199801/02)28:1<23::AID-EJSP843>3.0.CO;2-Z

White, R., \& Gunstone, R. (1998). Probing understanding. USA, The Falmer Press.

Williams, T., Wetton, N., \& Moon, A. (1989). A picture of health: What do you do that makes you healthy and keeps you healthy? London: Health Education Authority. Retrieved from http://www.styd-cevreorman.gov.tr/su_kirliligi.htm

Yildirim, A., \& Simsek, H. (2006). Qualitative research methods in social sciences. Ankara: Seckin Publishing. Zuckerman, J. T. (1998). Representations of an osmosis problem. The American Biology Teacher, 60(1), 27-30.

\section{Copyrights}

Copyright for this article is retained by the author(s), with first publication rights granted to the journal.

This is an open-access article distributed under the terms and conditions of the Creative Commons Attribution license (http://creativecommons.org/licenses/by/4.0/). 